\title{
Bench-Stable, Substrate-Activated Cobalt Carboxylate Pre-Catalysts for Alkene Hydrosilylation with Tertiary Silanes
}

\author{
Christopher H. Schuster, Tianning Diao, Iraklis Pappas, and Paul J. Chirik* \\ Department of Chemistry, Frick Laboratory, Princeton University, Princeton, New Jersey 08544, \\ United States \\ pchirik@princeton.edu
}




\section{Table of Contents}

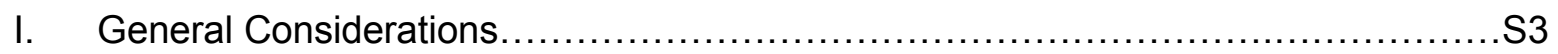

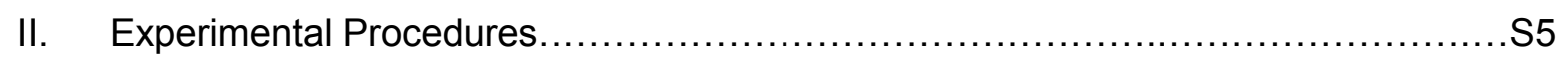

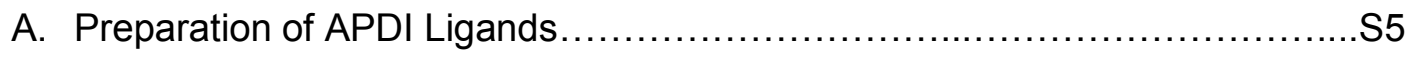

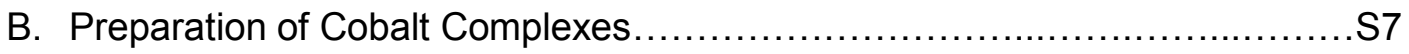

C. General Procedures for Catalytic Hydrosilylation Reactions.................S12

D. Synthesis and Characterization of Silane Products........................ 14

E. Procedure for 10 gram Scale Hydrosilylation of AGE $\ldots \ldots \ldots \ldots \ldots \ldots \ldots \ldots . . .520$

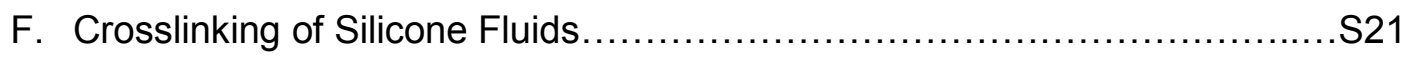

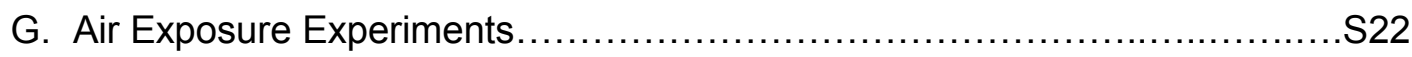

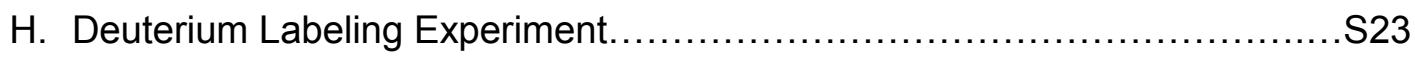

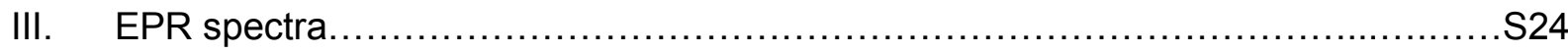

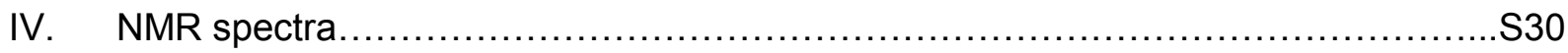

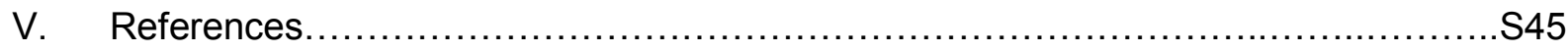




\section{General Considerations}

All air and moisture sensitive manipulations were carried out using standard vacuum line, Schlenk, and cannula techniques or in an MBraun inert atmosphere dry box containing an atmosphere of purified nitrogen. Solvents for air and moisture sensitive manipulations were initially dried and deoxygenated following the literature procedure. ${ }^{1}$ Chloroform- $d$ and benzene$d_{6}$ were purchased from Cambridge Isotope Laboratories. Bis(trimethylsiloxy)methylsilane $\left(\mathrm{MD}^{\mathrm{H}} \mathrm{M}\right),(\mathrm{EtO})_{3} \mathrm{SiH}$ and $\mathrm{Et}_{3} \mathrm{SiH}$ were obtained from Momentive Performance Materials, dried over calcium hydride and distilled under reduced pressure prior to use. Other silanes were purchased from either Aldrich or Gelest, dried over calcium hydride and distilled under reduced pressure prior to use. 1-Octene and allyl glycidyl ether were purchased from Aldrich, dried over calcium hydride and distilled under reduced pressure before use. Cobalt(2-ethylhexanoate) ${ }_{2}$ $\left(\mathrm{Co}(2-\mathrm{EH})_{2}\right)$ was purchased from Aldrich as a $65 \mathrm{wt} \%$ solution in mineral spirits and was used as received. SilForce ${ }^{\circledR}$ SL6100 $\left(\mathrm{M}^{\mathrm{vi}} \mathrm{D}_{120} \mathrm{M}^{\mathrm{vi}}\right)$ and SilForce ${ }^{\circledR} \mathrm{SL6020}\left(\mathrm{MD}_{15} \mathrm{D}^{\mathrm{H}}{ }_{30} \mathrm{M}\right)$ were acquired from Momentive Performance Materials and dried under high vacuum for 12 hours before use. PyBox was prepared according to the literature procedure ${ }^{2}$ and dried under high vacuum for 12 hours prior to use. Cobalt(II) pivalate was prepared according to the literature procedure ${ }^{9}$ and dried under high vacuum with periodic heating prior to use. (EtO) $)_{3} \mathrm{Si}-\mathrm{D}$ was prepared according to the literature procedure. ${ }^{6}$ All other materials were obtained from either Aldrich or Fisher and were either used as received, or dried over calcium hydride and distilled under reduced pressure prior to use.

${ }^{1} \mathrm{H}$ NMR spectra were recorded using Bruker ADVANCE 300 and 500 spectrometers operating at $300.13 \mathrm{MHz}$, and $500.62 \mathrm{MHz}$, respectively. Chemical shifts are reported in ppm with the solvent resonance as the internal standard $\left(\mathrm{CDCl}_{3}: 7.26 \mathrm{ppm}\right.$ or $\left.\mathrm{C}_{6} \mathrm{D}_{6}: 7.16 \mathrm{ppm}\right)$. Data are reported as follows: chemical shift, integration, multiplicity $(s=$ singlet, $d=$ doublet, $t=$ triplet, $q=$ 
quartet, $\mathrm{p}=$ pentet, $\mathrm{br}=$ broad, $\mathrm{m}=$ multiplet, app = apparent $)$, and coupling constants $(\mathrm{Hz})$. Data for paramagnetic compounds are reported as follows: chemical shift, multiplicity, peak width at half height $(\mathrm{Hz})$, and integration. ${ }^{13} \mathrm{C}$ NMR spectra were recorded using a Bruker ADVANCE 500 spectrometer operating at $125.893 \mathrm{MHz}$. Chemical shifts are reported in ppm with the solvent resonance as the internal standard $\left(\mathrm{CDCl}_{3}: 77.16 \mathrm{ppm}\right.$ or $\left.\mathrm{C}_{6} \mathrm{D}_{6}: 128.06 \mathrm{ppm}\right)$. Continuous wave EPR spectra were recorded at $10 \mathrm{~K}$ on an X-band Bruker EMXPlus spectrometer equipped with an EMX standard resonator and a Bruker PremiumX microwave bridge. The spectra were simulated using EasySpin for MATLAB. GC analysis was performed using a Shimadzu GC-2010 gas chromatograph equipped with a Shimadzu AOC-20s autosampler and a Shimadzu SHRXI-5MS capillary column (15 m x $250 \mu \mathrm{m})$. The instrument was set to an injection volume of $1 \mu \mathrm{L}$, an inlet split ratio of $20: 1$, and inlet and detector temperatures of $250{ }^{\circ} \mathrm{C}$ and $275^{\circ} \mathrm{C}$, respectively. UHP-grade helium was used as carrier gas with a flow rate of $1.82 \mathrm{~mL} / \mathrm{min}$. The temperature program used for all the analyses is as follows: $60.0^{\circ} \mathrm{C}, 1 \mathrm{~min} ; 15^{\circ} \mathrm{C} / \mathrm{min}$ to $250{ }^{\circ} \mathrm{C}, 2 \mathrm{~min}$. Elemental analyses were performed at Robertson Microlit Laboratories, Inc., in Ledgewood, NJ. Infrared spectroscopy was conducted on a Thermo-Nicolet iS10 FT-IR spectrometer calibrated with a polystyrene standard. Gouy magnetic susceptibility balance measurements were performed with a Johnson Matthey instrument that was calibrated with $\mathrm{HgCo}(\mathrm{SCN})_{4}$. Single crystals suitable for X-ray diffraction were coated with polyisobutylene oil in a drybox, transferred to a nylon loop and then quickly transferred to the goniometer head of a Bruker SMART APEX DUO diffractometer equipped with a molybdenum X-ray tube $(\lambda=0.71073 \AA)$ and a Cu X-ray tube $(\lambda=1.54178 \AA)$. Preliminary data revealed the crystal system. The data collection strategy was optimized for completeness and redundancy using the Bruker COSMO software suite. The space group was identified, and the data were processed using the Bruker SAINT+ program and corrected for absorption using SADABS. The structures were solved using direct methods (SHELXS) completed by subsequent Fourier synthesis and refined by full-matrix least-squares procedures. 


\section{Experimental Procedures}

\section{A. Preparation of APDI Ligands}

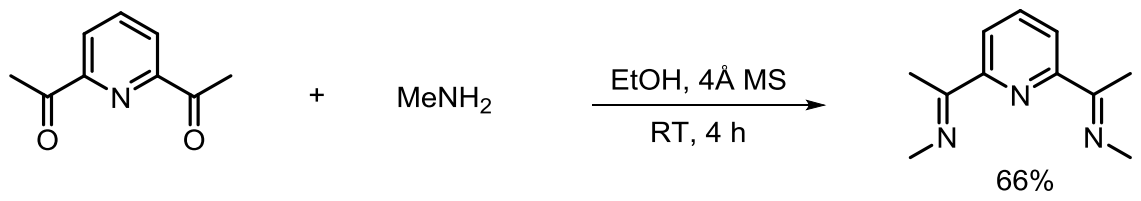

Preparation of ${ }^{\mathrm{Me}}$ APDI. To a $500 \mathrm{~mL}$ round-bottomed flask equipped with stir bar was added 2,6-diacetylpyridine $(10.0 \mathrm{~g}, 61.29 \mathrm{mmol})$, followed by activated $4 \AA$ mol. sieves $(0.5 \mathrm{~g})$. Methylamine (as a 33\% wt solution in ethanol from Aldrich, $38.2 \mathrm{~mL}, 306 \mathrm{mmol}$ ) was then added via syringe and the flask was sealed with a septum equipped with a small needle vent. After stirring at room temperature for 3.5 hours, an additional portion of methylamine solution (10.0 $\mathrm{mL}$ ) was added and the resulting cloudy mixture was stirred for an additional 30 minutes at room temperature. The reaction mixture was filtered through a pad of Celite on a glass frit with the use of $\mathrm{CH}_{2} \mathrm{Cl}_{2}(100 \mathrm{~mL})$ to dissolve all solids. The resulting clear, yellow filtrate was concentrated under reduced pressure to yield a white-yellow solid. The crude material was then recrystallized from hot hexane to afford a white solid which was subsequently dried overnight under high vacuum to furnish the product as a white solid $(7.69 \mathrm{~g}, 66 \%) .{ }^{1} \mathrm{H} \mathrm{NMR}(500 \mathrm{MHz}$, $\left.\mathrm{C}_{6} \mathrm{D}_{6}\right): \delta=8.36(2 \mathrm{H}, \mathrm{d}, J=7.5 \mathrm{~Hz}), 7.22(1 \mathrm{H}, \mathrm{t}, J=7.5 \mathrm{~Hz}), 3.21(6 \mathrm{H}, \mathrm{s}), 2.22(6 \mathrm{H}, \mathrm{s}) .{ }^{13} \mathrm{C}$ NMR $\left(125 \mathrm{MHz}, \mathrm{C}_{6} \mathrm{D}_{6}\right): \delta=167.5,156.5,136.5,121.2,39.7,12.8$.<smiles>C=CN1CCCC1=O</smiles>

i) $\mathrm{NaH}, \mathrm{THF}, \mathrm{RT}$ to reflux ii) $\mathrm{HCl}, 0^{\circ} \mathrm{C}$ to reflux

iii) $\mathrm{NaOH}, \mathrm{H}_{2} \mathrm{O}$

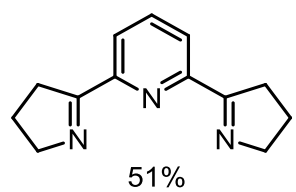


Preparation of ${ }^{\mathrm{TF}}$ APDI. Prepared according to the literature ${ }^{3}$ procedure with slight modification. To a $250 \mathrm{~mL}$ 3-neck round bottomed flask equipped with stir bar was added $\mathrm{NaH}(60 \%$ wt. in mineral oil, $4.50 \mathrm{~g}, 113 \mathrm{mmol})$. The flask was equipped with a reflux condenser with attached Schlenk line inlet and the remaining two necks were sealed with septa. The apparatus was evacuated and backfilled with argon (x3). Tetrahydrofuran $(100 \mathrm{~mL})$ was added via syringe through the septum followed by 2,6-pyridinedicarboxylic acid dimethylester $(4.88 \mathrm{~g}, 25.0 \mathrm{mmol})$ by quickly removing a septum under positive argon. $\mathrm{N}$-vinylpyrolidinone $(5.88 \mathrm{~mL}, 55.0 \mathrm{mmol})$ was then added via syringe and the resulting mixture was heated to reflux for 2 hours. During reflux, the reaction mixture becomes bright yellow with large amounts of precipitate formed. The resulting mixture was cooled to room temperature, then to $0{ }^{\circ} \mathrm{C}$ in an ice water bath and slowly treated with aqueous $\mathrm{HCl}(4 \mathrm{M}, 50 \mathrm{~mL})$. The resulting mixture was transferred to a 500 $\mathrm{mL}$ round bottomed flask and the tetrahydrofuran was removed under reduced pressure. Additional aqueous $\mathrm{HCl}(4 \mathrm{M}, 90 \mathrm{~mL})$ was added and the mixture was heated to reflux for 12 hours. The resulting dark reaction mixture was cooled to room temperature, transferred to a separatory funnel and washed with hexane $(3 \times 50 \mathrm{~mL})$. The aqueous layer was collected and cooled to $0{ }^{\circ} \mathrm{C}$ in an ice water bath. The cooled mixture was made basic with the slow addition of aqueous $\mathrm{NaOH}(6.8 \mathrm{M}, 100 \mathrm{~mL})$. During addition of base, a light colored precipitate is formed which was collected on a glass frit and washed with a small amount of cold water. The resulting light tan solid was dried under high vacuum to give the desired product as an off-white powder (2.70 g, 51\%). ${ }^{1} \mathrm{H}$ NMR (300 MHz, $\left.\mathrm{CDCl}_{3}\right): \delta=8.13(2 \mathrm{H}, \mathrm{d}, J=7.8 \mathrm{~Hz}), 7.78(1 \mathrm{H}, \mathrm{t}, J=7.8 \mathrm{~Hz})$, $4.11(4 \mathrm{H}, \mathrm{t}, J=7.5 \mathrm{~Hz}), 3.14(4 \mathrm{H}, \mathrm{t}, J=8.1 \mathrm{~Hz}), 2.04(4 \mathrm{H}$, app. pentet, $J=7.8 \mathrm{~Hz}) .{ }^{13} \mathrm{C}$ NMR $\left(125 \mathrm{MHz}, \mathrm{CDCl}_{3}\right): \delta=175.6,152.7,136.7,122.5,62.4,35.0,22.6$. All spectra are in agreement with literature values. ${ }^{3}$ 


\section{B. Preparation of Cobalt Complexes}

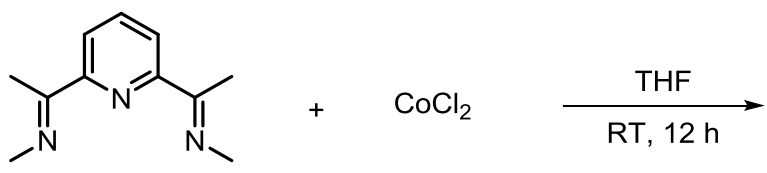

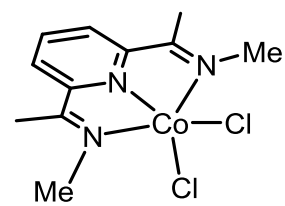

$(86 \%)$

Preparation of $\left({ }^{\mathrm{Me}} \mathrm{APDI}\right) \mathrm{CoCl}_{2}$. To a $20 \mathrm{~mL}$ scintillation vial equipped with a stir bar in a nitrogen filled glove box was added anhydrous cobalt(II) chloride $(1.133 \mathrm{~g}, 8.73 \mathrm{mmol})$ followed by THF (15 mL). To the stirring mixture was then added a THF solution of Me APDI (1.652 $\mathrm{g}, 8.73$ mmol, $1 \mathrm{~mL}$ ) in one portion and an immediate color change to dark purple was observed. The mixture was stirred at room temperature for 12 hours, after which the mixture was filtered on a glass frit with additional pentane rinses. The solid was dried under vacuum to give the product as a dark purple solid $(2.402 \mathrm{~g}, 86 \%)$. Magnetic susceptibility: $\mu_{\text {eff }}$ (magnetic susceptibility balance, $\left.23{ }^{\circ} \mathrm{C}\right)=4.0 \mu \mathrm{B}$. Anal. for $\mathrm{C}_{11} \mathrm{H}_{15} \mathrm{Cl}_{2} \mathrm{CoN}_{3}$ : calc. $=\mathrm{C}, 41.40 ; \mathrm{H}, 4.74 ; \mathrm{N}, 13.17$. Found $=$ C, 41.67; H, 4.72; N, 12.83.
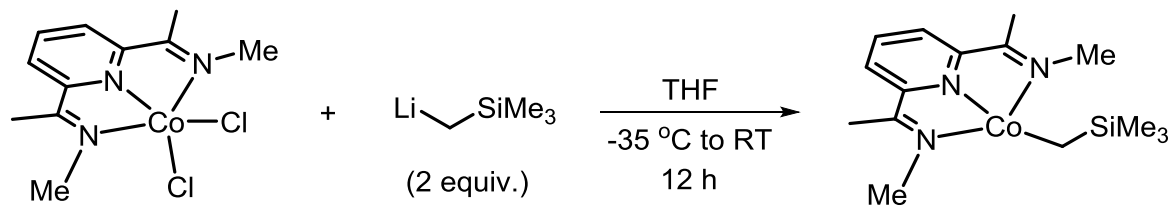

$(42 \%)$

Preparation of ( $\left.{ }^{\mathrm{Me}} \mathrm{APDI}\right) \mathrm{Co}\left(\mathrm{CH}_{2} \mathrm{SiMe}_{3}\right)$. To a scintillation vial equipped with a stir bar in a nitrogen filled glove box was added ( $\left.{ }^{\mathrm{Me}} \mathrm{APDI}\right) \mathrm{CoCl}_{2}(0.350 \mathrm{~g}, 1.10 \mathrm{mmol})$ followed by THF (14 $\mathrm{mL}$ ). The resulting suspension was chilled at $-35^{\circ} \mathrm{C}$ for 20 minutes followed by dropwise addition of a THF solution of (trimethylsilyl)methyllithium ( $0.207 \mathrm{~g}$ in $3 \mathrm{~mL}$ THF), during which a color change to purple was observed. The reaction mixture was stirred at room temperature overnight, after which the volatiles were removed under reduced pressure. The residue was extracted with diethyl ether, filtered through Celite, and concentrated. Layering the supernatant 
with pentane and recrystallization at $-35^{\circ} \mathrm{C}$ yielded the product as a purple solid $(0.155 \mathrm{~g}, 42 \%)$. ${ }^{1} \mathrm{H}$ NMR (benzene- $\left.d_{6}, 23^{\circ} \mathrm{C}\right): \delta=9.83(\mathrm{t}, 1 \mathrm{H}, J=8 \mathrm{~Hz}), 7.21(\mathrm{~d}, 2 \mathrm{H}, J=8 \mathrm{~Hz}), 3.98(\mathrm{~s}, 6 \mathrm{H}), 1.22$ $(\mathrm{s}, 2 \mathrm{H}),-0.11(\mathrm{~s}, 9 \mathrm{H}),-0.57(\mathrm{~s}, 6 \mathrm{H}) .{ }^{13} \mathrm{C}$ NMR (benzene- $\left.d_{6}, 23{ }^{\circ} \mathrm{C}\right): \delta=165.3,152.5,122.4$, 114.0, 48.3, 30.3, 21.0, 3.4. Anal. for $\mathrm{C}_{15} \mathrm{H}_{26} \mathrm{CoN}_{3} \mathrm{Si}$ : calc. $=\mathrm{C}, 53.71 ; \mathrm{H}, 7.81 ; \mathrm{N}, 12.53$. Found $=\mathrm{C}, 53.84 ; \mathrm{H}, 7.42 ; \mathrm{N}, 12.72$.
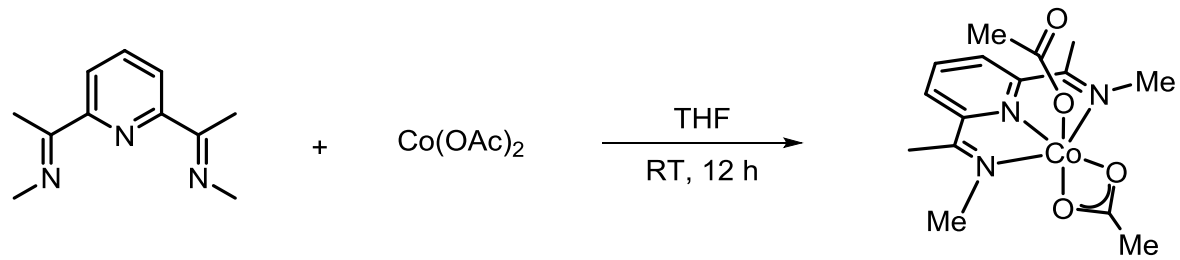

$(67 \%)$

Preparation of ( $\left.{ }^{\mathrm{Me}} \mathrm{APDI}\right) \mathrm{Co}(\mathrm{OAc})_{2}$. To a scintillation vial equipped with a stir bar was added ${ }^{\mathrm{Me}} \mathrm{APDI}(200 \mathrm{mg}, 1.06 \mathrm{mmol})$ followed by anhydrous Co(OAc) $)_{2}(187 \mathrm{mg}, 1.06 \mathrm{mmol})$. Tetrahydrofuran $(5 \mathrm{~mL})$ was then added and the resulting light brown mixture was rapidly stirred at ambient temperature for 12 hours to produce a dark brown mixture. The solvent was removed under reduced pressure and the resulting brown solid material was suspended in diethyl ether and collected by filtration onto a glass frit with additional diethyl ether rinses. The solid was dried under vacuum to yield the product as a light brown powder $(261 \mathrm{mg}, 67 \%) .{ }^{1} \mathrm{H}$ NMR $(300 \mathrm{MHz}$, $\left.\mathrm{CDCl}_{3}, 23^{\circ} \mathrm{C}\right): \delta=90.49\left(\mathrm{~s}, \Delta \mathrm{u}_{1 / 2}=69 \mathrm{~Hz}, 2 \mathrm{H}\right), 64.22\left(\mathrm{~s}, \Delta \mathrm{u}_{1 / 2}=121 \mathrm{~Hz}, 6 \mathrm{H}\right), 47.04\left(\mathrm{~s}, \Delta \mathrm{u}_{1 / 2}=90\right.$ $\mathrm{Hz}, 6 \mathrm{H}), 16.42\left(\mathrm{~s}, \Delta \mathrm{U}_{1 / 2}=58 \mathrm{~Hz}, 1 \mathrm{H}\right),-5.69\left(\mathrm{~s}, \Delta \mathrm{U}_{1 / 2}=66 \mathrm{~Hz}, 6 \mathrm{H}\right) . \mathrm{IR}($ powder$) \mathrm{U}_{\mathrm{CO} 2}=1560 \mathrm{~cm}^{-1}$. Magnetic susceptibility: $\mu_{\text {eff }}$ (magnetic susceptibility balance, $23{ }^{\circ} \mathrm{C}$ ) $=4.4 \mu \mathrm{B}$. Anal. for $\mathrm{C}_{15} \mathrm{H}_{21} \mathrm{CoN}_{3} \mathrm{O}_{4}$ : calc. $=\mathrm{C}, 49.19 ; \mathrm{H}, 5.78 ; \mathrm{N}, 11.47$. Found $=\mathrm{C}, 49.05 ; \mathrm{H}, 5.63 ; \mathrm{N}, 11.35$. 


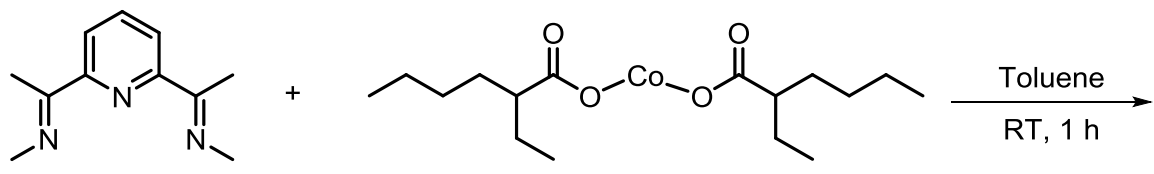

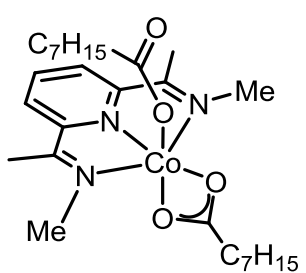

$(94 \%)$

Preparation of ( $\left.{ }^{\mathrm{Me}} \mathrm{APDI}\right) \mathrm{Co}(2-\mathrm{EH})_{2}$. To a $250 \mathrm{~mL}$ round-bottomed flask equipped with a stir bar on the benchtop was added ${ }^{\mathrm{Me}}$ APDI $(1.00 \mathrm{~g}, 5.28 \mathrm{mmol})$ followed by toluene $(50 \mathrm{~mL})$ to give a clear, slightly yellow solution. Cobalt(II) 2-ethylhexanoate (as a $65 \mathrm{wt} \%$ solution in mineral spirits, $2.80 \mathrm{~mL}, 5.28 \mathrm{mmol}$ ) was then added in one portion via syringe and the resulting dark brown reaction mixture was rapidly stirred at room temperature for 1 hour. The flask was then equipped with a vacuum adapter and the solvent and mineral spirits were removed under reduced pressure. The resulting dark brown solid material was ground to a powder and further dried under high vacuum overnight to give the product as a medium brown powder (2.65 g, 94\%). ${ }^{1} \mathrm{H}$ NMR $\left(300 \mathrm{MHz}, \mathrm{CDCl}_{3}, 23^{\circ} \mathrm{C}\right): \delta=92.89\left(\mathrm{~s}, \Delta \mathrm{u}_{1 / 2}=33 \mathrm{~Hz}, 1 \mathrm{H}\right), 64.04\left(\mathrm{~s}, \Delta \mathrm{u}_{1 / 2}=432\right.$ $\mathrm{Hz}, 1 \mathrm{H}), 51.21\left(\mathrm{~s}, \Delta \mathrm{U}_{1 / 2}=94 \mathrm{~Hz}, 4 \mathrm{H}\right), 12.94\left(\mathrm{~s}, \Delta \mathrm{U}_{1 / 2}=27 \mathrm{~Hz}, 1 \mathrm{H}\right), 11.41\left(\mathrm{~s}, \Delta \mathrm{U}_{1 / 2}=343 \mathrm{~Hz}, 4 \mathrm{H}\right)$, $8.79\left(\mathrm{~s}, \Delta \mathrm{u}_{1 / 2}=284 \mathrm{~Hz}, 4 \mathrm{H}\right),-0.77-4.02(\mathrm{~m}, 24 \mathrm{H}),-7.69\left(\mathrm{~s}, \Delta \mathrm{u}_{1 / 2}=20 \mathrm{~Hz}, 6 \mathrm{H}\right) . \mathrm{IR}($ powder $) \mathrm{U}_{\mathrm{CO} 2}=$ $1551 \mathrm{~cm}^{-1}$. Magnetic susceptibility: $\mu_{\mathrm{eff}}$ (magnetic susceptibility balance, $\left.23^{\circ} \mathrm{C}\right)=4.1 \mu \mathrm{B}$. Anal. for $\mathrm{C}_{27} \mathrm{H}_{45} \mathrm{CoN}_{3} \mathrm{O}_{4}$ : calc. $=\mathrm{C}, 60.66 ; \mathrm{H}, 8.48 ; \mathrm{N}, 7.86$. Found $=\mathrm{C}, 60.65 ; \mathrm{H}, 8.37 ; \mathrm{N}, 7.46$. HRMS-(ESI-TOF) for $\mathrm{C}_{27} \mathrm{H}_{45} \mathrm{CoN}_{3} \mathrm{O}_{4}[\mathrm{M}]^{+}$: calculated: 534.2742, found: 534.2740.
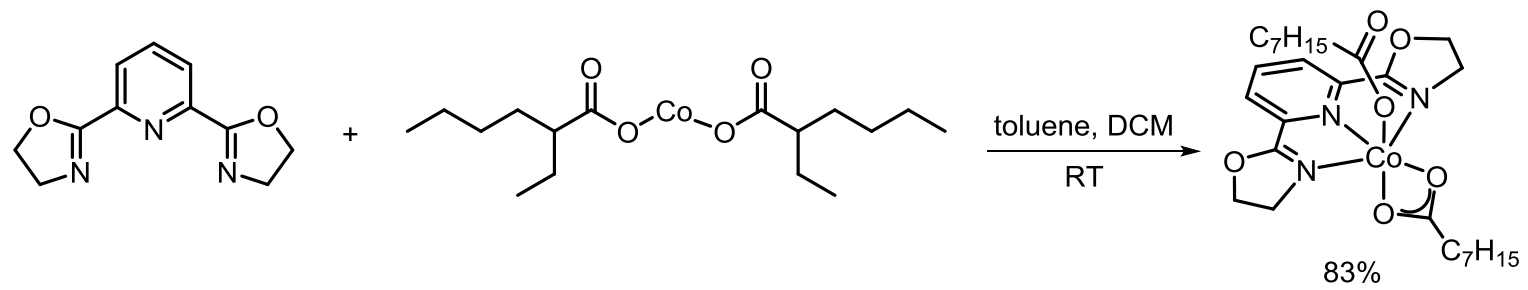

Preparation of (PyBox)Co(2-EH) 2. To a $50 \mathrm{~mL}$ round-bottomed flask equipped with a stir bar on the benchtop was added PyBox $(200 \mathrm{mg}, 0.921 \mathrm{mmol})$ followed by toluene $(15 \mathrm{~mL})$ and a small amount of dichloromethane $(3 \mathrm{~mL})$ to give a clear, slightly yellow solution. Cobalt(II) 2- 
ethylhexanoate (as a $65 \mathrm{wt} \%$ solution in mineral spirits from Aldrich, $0.490 \mathrm{~mL}, 0.921 \mathrm{mmol}$ ) was then added in one portion via syringe and the resulting dark brown reaction mixture was rapidly stirred at room temperature for 2 hours. The flask was then equipped with a vacuum adapter and the solvent and mineral spirits were removed under reduced pressure. The resulting dark grey-brown solid material was ground to a powder and further dried under high vacuum overnight to give the product as a grey slightly purple powder (431 mg, 83\%). ${ }^{1} \mathrm{H}$ NMR $\left(300 \mathrm{MHz}, \mathrm{CDCl}_{3}, 23^{\circ} \mathrm{C}\right): \delta=89.34\left(\mathrm{~s}, \Delta \mathrm{u}_{1 / 2}=116 \mathrm{~Hz}, 1 \mathrm{H}\right), 54.39\left(\mathrm{~s}, \Delta \mathrm{u}_{1 / 2}=43 \mathrm{~Hz}, 2 \mathrm{H}\right), 20.76$, 20.52 (overlapping signals, $7 \mathrm{H}$ ), $10.73\left(\mathrm{~s}, \Delta \mathrm{U}_{1 / 2}=70 \mathrm{~Hz}, 2 \mathrm{H}\right.$ ), $9.05\left(\mathrm{~s}, \Delta \mathrm{U}_{1 / 2}=78 \mathrm{~Hz}, 2 \mathrm{H}\right), 8.10$ (s, $\left.\Delta \mathrm{U}_{1 / 2}=64 \mathrm{~Hz}, 6 \mathrm{H}\right), 4.89\left(\mathrm{~s}, \Delta \mathrm{U}_{1 / 2}=64 \mathrm{~Hz}, 2 \mathrm{H}\right), 4.43(\mathrm{~s}, 71 \mathrm{~Hz}, 2 \mathrm{H}), 2.81\left(\mathrm{~s}, \Delta \mathrm{U}_{1 / 2}=39 \mathrm{~Hz}, 1 \mathrm{H}\right)$, $0.74\left(\mathrm{~s}, \Delta \mathrm{U}_{1 / 2}=35 \mathrm{~Hz}, 8 \mathrm{H}\right),-10.73\left(\mathrm{~s}, \Delta \mathrm{U}_{1 / 2}=40 \mathrm{~Hz}, 4 \mathrm{H}\right),-30.03\left(\mathrm{~s}, \Delta \mathrm{U}_{1 / 2}=100 \mathrm{~Hz}, 4 \mathrm{H}\right)$. $\operatorname{IR}$ (powder) $\mathrm{U}_{\mathrm{CO} 2}=1578 \mathrm{~cm}^{-1}$. Magnetic susceptibility: $\mu_{\text {eff }}$ (magnetic susceptibility balance, 23 $\left.{ }^{\circ} \mathrm{C}\right)=4.8 \mu \mathrm{B}$. Anal. for $\mathrm{C}_{27} \mathrm{H}_{41} \mathrm{CoN}_{3} \mathrm{O}_{6}$ : calc. $=\mathrm{C}, 57.65 ; \mathrm{H}, 7.35 ; \mathrm{N}, 7.47$. Found $=\mathrm{C}, 57.35 ; \mathrm{H}$, $7.26 ; \mathrm{N}, 7.33$.
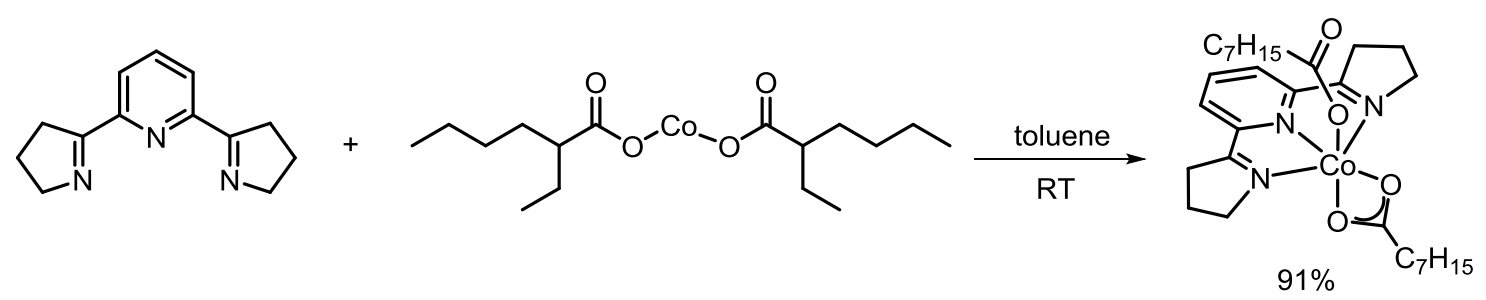

Preparation of ( ${ }^{\mathrm{TF}}$ APDI)Co(2-ethylhexanoate) ${ }_{2}$. To a $100 \mathrm{~mL}$ round-bottomed flask equipped with a stir bar on the benchtop was added ${ }^{\mathrm{TF}} \mathrm{APDI}(500 \mathrm{mg}, 2.34 \mathrm{mmol})$ followed by toluene (20 $\mathrm{mL}$ ) to give a clear, slightly yellow solution. Cobalt(II) 2-ethylhexanoate (as a $65 \mathrm{wt} \%$ solution in mineral spirits from Aldrich, $1.24 \mathrm{~mL}, 2.34 \mathrm{mmol}$ ) was then added in one portion via syringe and the resulting dark brown reaction mixture was rapidly stirred at room temperature for 1 hour. The flask was then equipped with a vacuum adapter and the solvent and mineral spirits were removed under reduced pressure. The resulting brown solid material was ground to a powder and further dried under high vacuum overnight to give the product as a medium brown powder (1.19 g, 91\%). ${ }^{1} \mathrm{H}$ NMR (300 MHz, $\left.\mathrm{CDCl}_{3}, 23{ }^{\circ} \mathrm{C}\right): \delta=76.17\left(\mathrm{~s}, \Delta \mathrm{U}_{1 / 2}=65 \mathrm{~Hz}, 2 \mathrm{H}\right), 71.12(\mathrm{~s}$, 
$\left.\Delta \mathrm{U}_{1 / 2}=27 \mathrm{~Hz}, 2 \mathrm{H}\right), 15.87,15.77$ (overlapping signals, $4 \mathrm{H}$ ), $14.74\left(\mathrm{~s}, \Delta \mathrm{U}_{1 / 2}=69 \mathrm{~Hz}, 4 \mathrm{H}\right), 7.35(\mathrm{~s}$, $\left.\Delta \mathrm{U}_{1 / 2}=22 \mathrm{~Hz}, 1 \mathrm{H}\right), 7.09\left(\mathrm{~s}, \Delta \mathrm{U}_{1 / 2}=42 \mathrm{~Hz}, 2 \mathrm{H}\right), 5.17\left(\mathrm{~s}, \Delta \mathrm{U}_{1 / 2}=34 \mathrm{~Hz}, 8 \mathrm{H}\right), 3.32(\mathrm{~s}, 36 \mathrm{~Hz}, 2 \mathrm{H})$, $2.92\left(\mathrm{~s}, \Delta \mathrm{U}_{1 / 2}=36 \mathrm{~Hz}, 2 \mathrm{H}\right), 0.25\left(\mathrm{~s}, \Delta \mathrm{U}_{1 / 2}=18 \mathrm{~Hz}, 6 \mathrm{H}\right),-7.38\left(\mathrm{~s}, \Delta \mathrm{U}_{1 / 2}=26 \mathrm{~Hz}, 4 \mathrm{H}\right),-19.58(\mathrm{~s}$, $\left.\Delta \mathrm{U}_{1 / 2}=81 \mathrm{~Hz}, 4 \mathrm{H}\right),-21.18\left(\mathrm{~s}, \Delta \mathrm{U}_{1 / 2}=30 \mathrm{~Hz}, 4 \mathrm{H}\right) . \quad \mathrm{IR}($ powder $) \mathrm{U}_{\mathrm{CO} 2}=1585 \mathrm{~cm}^{-1}$. Magnetic susceptibility: $\mu_{\text {eff }}$ (magnetic susceptibility balance, $\left.23{ }^{\circ} \mathrm{C}\right)=4.3 \mu \mathrm{B}$. Anal. for $\mathrm{C}_{29} \mathrm{H}_{45} \mathrm{CoN}_{3} \mathrm{O}_{4}$ : calc. = C, 62.35; H, 8.12; N, 7.52. Found = C, 62.01; H, 7.98; N, 7.39.
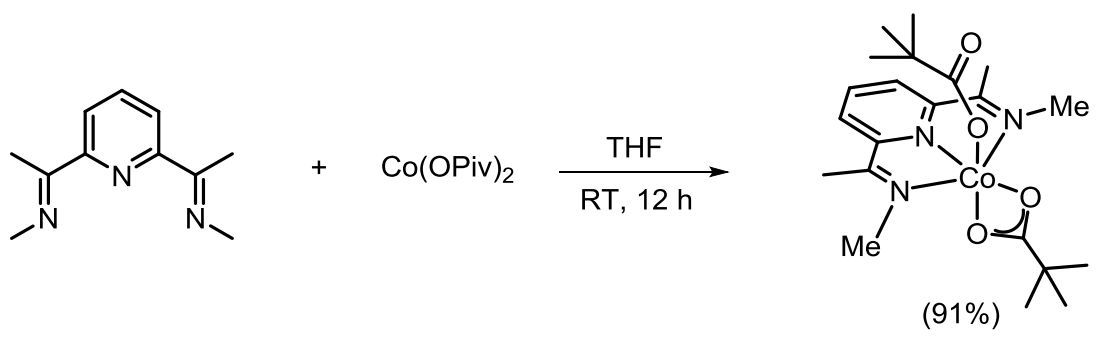

Preparation of ( $\left.{ }^{\mathrm{Me}} \mathrm{APDI}\right) \mathrm{Co}(\mathrm{OPiv})_{2}$. To a scintillation vial equipped with stir bar in the glove box was added ${ }^{\mathrm{Me}} \mathrm{APDI}(200 \mathrm{mg}, 1.06 \mathrm{mmol})$ followed by Co(OPiv) $)_{2}(276 \mathrm{mg}, 1.06 \mathrm{mmol})$. Tetrahydrofuran $(8 \mathrm{~mL})$ was added and the vial was sealed with a cap and stirred for 12 hours at room temperature. The resulting orange brown mixture was concentrated under reduced pressure followed by trituration of the resulting material with pentane to give the product as an orange powder (432 mg, 91\%). Crystals suitable for x-ray diffraction were obtained from a tetrahydrofuran solution of the complex held at $-35^{\circ} \mathrm{C}$ for 24 hours. ${ }^{1} \mathrm{H} \mathrm{NMR}\left(300 \mathrm{MHz}, \mathrm{CDCl}_{3}\right.$, $\left.23^{\circ} \mathrm{C}\right): \delta=87.12\left(\mathrm{~s}, \Delta \mathrm{U}_{1 / 2}=32 \mathrm{~Hz}, 2 \mathrm{H}\right), 69.66\left(\mathrm{~s}, \Delta \mathrm{U}_{1 / 2}=74 \mathrm{~Hz}, 6 \mathrm{H}\right), 18.59\left(\mathrm{~s}, \Delta \mathrm{U}_{1 / 2}=17 \mathrm{~Hz}, 1 \mathrm{H}\right)$, $15.39\left(\mathrm{~s}, \Delta \mathrm{U}_{1 / 2}=152 \mathrm{~Hz}, 18 \mathrm{H}\right),-5.12\left(\mathrm{~s}, \Delta \mathrm{U}_{1 / 2}=16 \mathrm{~Hz}, 6 \mathrm{H}\right) . \operatorname{IR}($ powder$) \mathrm{U}_{\mathrm{CO} 2}=1601 \mathrm{~cm}^{-1}$. Magnetic susceptibility: $\mu_{\text {eff }}$ (magnetic susceptibility balance, $23{ }^{\circ} \mathrm{C}$ ) $=4.1 \mu \mathrm{B}$. Anal. for $\mathrm{C}_{21} \mathrm{H}_{33} \mathrm{CoN}_{3} \mathrm{O}_{4}$ : calc. $=\mathrm{C}, 56.00 ; \mathrm{H}, 7.38 ; \mathrm{N}, 9.33$. Found $=\mathrm{C}, 55.76 ; \mathrm{H}, 7.24 ; \mathrm{N}, 9.27$. 


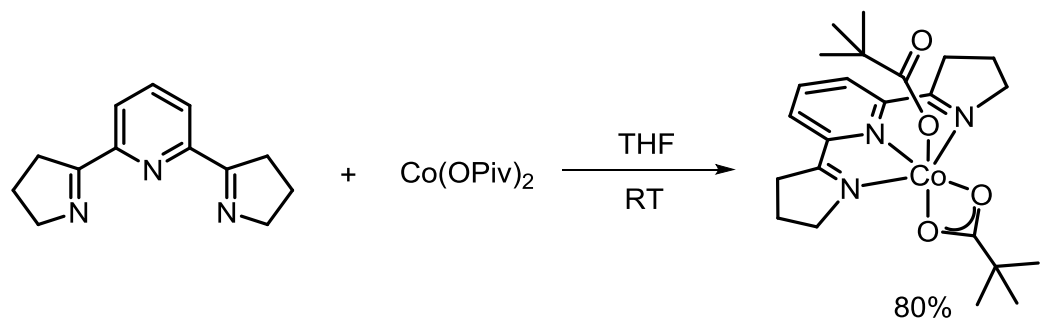

Preparation of ( $\left.{ }^{\mathrm{TF}} \mathrm{APDI}\right) \mathrm{Co}(\mathrm{OPiv})_{2}$. To a scintillation vial equipped with stir bar in the glove box was added ${ }^{\text {TFAPDI }}$ (200 mg, $0.938 \mathrm{mmol}$ ) followed by Co(OPiv) $)_{2}(245 \mathrm{mg}, 0.938 \mathrm{mmol})$. Tetrahydrofuran $(8 \mathrm{~mL})$ was added and the vial was sealed with a cap and stirred for 12 hours at room temperature. The resulting orange brown mixture was concentrated under reduced pressure followed by trituration of the resulting material with pentane to give the product as an orange-brown powder (432 mg, 91\%). Crystals suitable for x-ray diffraction were obtained by carefully layering pentane over a tetrahydrofuran solution of the complex at room temperature. ${ }^{1} \mathrm{H}$ NMR $\left(300 \mathrm{MHz}, \mathrm{CDCl}_{3}, 23{ }^{\circ} \mathrm{C}\right): \delta=68.18\left(\mathrm{~s}, \Delta \mathrm{U}_{1 / 2}=21 \mathrm{~Hz}, 2 \mathrm{H}\right), 19.33\left(\mathrm{~s}, \Delta \mathrm{u}_{1 / 2}=32 \mathrm{~Hz}\right.$, $18 \mathrm{H}), 10.55\left(\mathrm{~s}, \Delta \mathrm{U}_{1 / 2}=16 \mathrm{~Hz}, 1 \mathrm{H}\right),-3.23\left(\mathrm{~s}, \Delta \mathrm{U}_{1 / 2}=20 \mathrm{~Hz}, 4 \mathrm{H}\right),-11.21\left(\mathrm{~s}, \Delta \mathrm{U}_{1 / 2}=69 \mathrm{~Hz}, 4 \mathrm{H}\right),-$ $18.72\left(\mathrm{~s}, \Delta \mathrm{U}_{1 / 2}=22 \mathrm{~Hz}, 4 \mathrm{H}\right) . \quad \operatorname{IR}($ powder $) \mathrm{U}_{\mathrm{CO} 2}=1591 \mathrm{~cm}^{-1}$. Magnetic susceptibility: $\mu_{\text {eff }}$ (magnetic susceptibility balance, $23{ }^{\circ} \mathrm{C}$ ) $=4.0 \mu \mathrm{B}$. Anal. for $\mathrm{C}_{23} \mathrm{H}_{33} \mathrm{CoN}_{3} \mathrm{O}_{4}$ : calc. $=\mathrm{C}, 58.22 ; \mathrm{H}$, 7.01; N, 8.86. Found = C, 58.00; H, 7.18; N, 8.70.

\section{General Procedures for Catalytic Hydrosilylation Reactions}

Method A: To a scintillation vial equipped with a stir bar in a nitrogen filled glovebox is added cobalt carboxylate catalyst ( 0.01 equiv.) followed by olefin ( 1.00 equiv.) to give a heterogeneous mixture. Silane (1.00 equiv.) is then added resulting in formation of an olive green reaction mixture. The vial is sealed with a cap, removed from the box and stirred at room temperature for 1 hour. The cap is then removed and any remaining volatiles are removed with a stream of air. The resulting residue is diluted with a solution of $10 \%$ diethyl ether in pentane and passed through a small column of silica gel, eluting with additional $10 \%$ ether in pentane solution (5 
$\mathrm{mL}$ ). The resulting clear, colorless eluent is then concentrated under a stream of nitrogen to give the product.

Method B: To a scintillation vial equipped with a stir bar in a nitrogen filled glovebox is added cobalt carboxylate catalyst ( 0.0025 equiv. as a solution in toluene). The toluene is then removed under reduced pressure followed by addition of olefin (1.00 equiv.) to give a heterogeneous mixture. Silane (1.00 equiv.) is then added resulting in formation of an olive green reaction mixture. The vial is sealed with a cap, removed from the box and stirred at room temperature for 1 hour. The cap is then removed and any remaining volatiles are removed with a stream of air. The resulting residue is diluted with a solution of $10 \%$ diethyl ether in pentane and passed through a small column of silica gel, eluting with additional $10 \%$ ether in pentane solution $(5 \mathrm{~mL})$. The resulting clear, colorless eluent is then concentrated under a stream of nitrogen to give the product.

Method C: To a scintillation vial equipped with a stir bar in a nitrogen filled glovebox is added cobalt carboxylate catalyst $(0.0025$ equiv. as a solution in toluene). The toluene is then removed under reduced pressure followed by addition of silane (1.00 equiv.) to give an olive green mixture. The vial is sealed with a septum, removed from the box and placed in a room temperature water bath. Olefin (1.00 equiv. (non-dried, non-degassed)) is then added via syringe through the septum and stirred at room temperature for 1 hour. The septum is then removed and any remaining volatiles are removed with a stream of air. The resulting residue is diluted with a solution of $10 \%$ diethyl ether in pentane and passed through a small column of silica gel, eluting with additional $10 \%$ ether in pentane solution $(5 \mathrm{~mL})$. The resulting clear, colorless eluent is then concentrated under a stream of nitrogen to give the product. 


\section{Synthesis and Characterization of Silane Products}

$\widehat{S}_{\mathrm{Si}(\mathrm{OEt})_{3}}$ Triethoxy(octyl)silane. Prepared according to general method $\mathrm{A}$, using $\left({ }^{\mathrm{TF}} \mathrm{APDI}\right) \mathrm{Co}(2-\mathrm{EH})_{2}(5 \mathrm{mg}, 0.009 \mathrm{mmol})$, 1-octene $(100 \mathrm{mg}, 0.891 \mathrm{mmol})$, and triethoxysilane (146 mg, $0.891 \mathrm{mmol})$. Caution! Silane addition produces an exothermeric reaction and should be performed carefully. The product was isolated as a clear, colorless oil (241 mg, 98\%). ${ }^{1} \mathrm{H}$ NMR $\left(500 \mathrm{MHz}, \mathrm{CDCl}_{3}\right): \delta=3.81(6 \mathrm{H}, \mathrm{q}, J=7.0 \mathrm{~Hz}), 1.44-1.36(2 \mathrm{H}, \mathrm{m})$, 1.35-1.19 (10H, m), $1.22(9 \mathrm{H}, \mathrm{t}, J=7.0 \mathrm{~Hz}), 0.87(3 \mathrm{H}, \mathrm{t}, J=7.1 \mathrm{~Hz}), 0.66-0.59(2 \mathrm{H}, \mathrm{m}) .{ }^{13} \mathrm{C}$ $\operatorname{NMR}\left(125 \mathrm{MHz}, \mathrm{CDCl}_{3}\right.$ ): (one overlapping signal) $\delta=58.4,33.4,32.1,29.4,22.9,22.8,18.5$, 14.3, 10.5. All spectra are in accordance with the literature. ${ }^{4}$

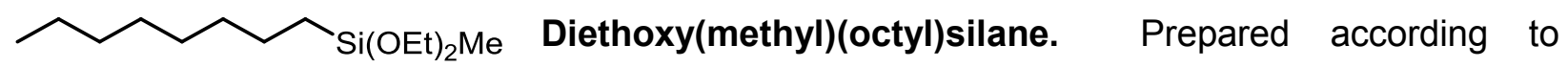
general method $\mathrm{B}$, using ( $\left.{ }^{\mathrm{TF}} \mathrm{APDI}\right) \mathrm{Co}(2-\mathrm{EH})_{2}(0.019 \mathrm{M}$ solution in toluene, $0.053 \mathrm{~mL}, 0.001$ $\mathrm{mmol})$, 1-octene $(112 \mathrm{mg}, 1.00 \mathrm{mmol})$, and diethoxy(methyl)silane (134 mg, $1.00 \mathrm{mmol})$. Caution! Silane addition produces an exothermeric reaction and should be performed carefully. The product was isolated as a clear, colorless oil $(232 \mathrm{mg}, 94 \%) .{ }^{1} \mathrm{H}$ NMR (500 $\left.\mathrm{MHz}, \mathrm{CDCl}_{3}\right): \delta=3.75(4 \mathrm{H}, \mathrm{q}, J=7.0 \mathrm{~Hz}), 1.39-1.18(12 \mathrm{H}, \mathrm{m}), 1.21(6 \mathrm{H}, \mathrm{t}, J=7.0 \mathrm{~Hz}), 0.87$ $(3 \mathrm{H}, \mathrm{t}, J=7.1 \mathrm{~Hz}), 0.64-0.57(2 \mathrm{H}, \mathrm{m}), 0.10(3 \mathrm{H}, \mathrm{s}) .{ }^{13} \mathrm{C} \mathrm{NMR}\left(125 \mathrm{MHz}, \mathrm{CDCl}_{3}\right): \delta=58.2,33.5$, $32.1,29.43,29.38,23.0,22.8,18.6,14.3,14.0,-4.7$.

$\widehat{S}_{\mathrm{Si}(\mathrm{OEt}) \mathrm{Me}_{2}}$ Ethoxydimethyl(octyl)silane. Prepared according to general method $\mathrm{B}$, using $\left({ }^{\mathrm{TF}} \mathrm{APDI}\right) \mathrm{Co}(2-\mathrm{EH})_{2}(0.019 \mathrm{M}$ solution in toluene, $0.053 \mathrm{~mL}, 0.001 \mathrm{mmol}), 1-$ octene (112 mg, $1.00 \mathrm{mmol})$, and ethoxydimethylsilane (104 mg, $1.00 \mathrm{mmol})$. Caution! Silane addition produces an exothermeric reaction and should be performed carefully. The product was isolated as a clear, colorless oil $(195 \mathrm{mg}, 90 \%)$. ${ }^{1} \mathrm{H}$ NMR $\left(500 \mathrm{MHz}, \mathrm{CDCl}_{3}\right): \delta=$ $3.65(2 \mathrm{H}, \mathrm{q}, J=7.0 \mathrm{~Hz}), 1.36-1.22(12 \mathrm{H}, \mathrm{m}), 1.18(3 \mathrm{H}, \mathrm{t}, J=7.0 \mathrm{~Hz}), 0.88(3 \mathrm{H}, \mathrm{t}, J=7.1 \mathrm{~Hz})$, 
0.62-0.54 (2H, m), $0.09(6 \mathrm{H}, \mathrm{s}) .{ }^{13} \mathrm{C} \operatorname{NMR}\left(125 \mathrm{MHz}, \mathrm{CDCl}_{3}\right): \delta=58.3,33.6,32.1,29.5,29.4$, 23.4, 22.8, 18.7, 16.5, 14.3, -1.9.

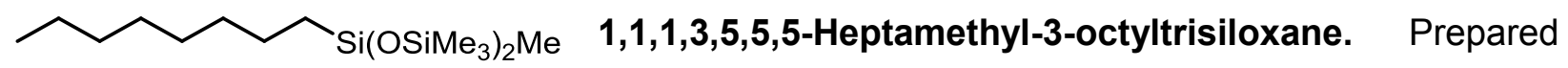
according to general method $\mathrm{A}$, using ( $\left.{ }^{\mathrm{TF}} \mathrm{APDI}\right) \mathrm{Co}(2-\mathrm{EH})_{2}(6 \mathrm{mg}, 0.01 \mathrm{mmol}), 1$-octene $(112 \mathrm{mg}$, $1.00 \mathrm{mmol})$, and 1,1,1,3,5,5,5-heptamethyltrisiloxane (223 $\mathrm{mg}, 1.00 \mathrm{mmol})$. The product was isolated as a clear, colorless oil (315 mg, 94\%). ${ }^{1} \mathrm{H}$ NMR $\left(500 \mathrm{MHz}, \mathrm{CDCl}_{3}\right): \delta=1.34-1.22$ $(12 \mathrm{H}, \mathrm{m}), 0.88(3 \mathrm{H}, \mathrm{t}, J=7.1 \mathrm{~Hz}), 0.48-0.41(2 \mathrm{H}, \mathrm{m}), 0.08(18 \mathrm{H}, \mathrm{s}),-0.01(3 \mathrm{H}, \mathrm{s}) .{ }^{13} \mathrm{C}$ NMR $(125$ $\left.\mathrm{MHz}_{\mathrm{CDCl}}\right): \delta=33.4,32.1,29.5,29.4,23.2,22.9,17.8,14.3,2.0,-0.1$. All spectra are in accordance with the literature. ${ }^{4}$

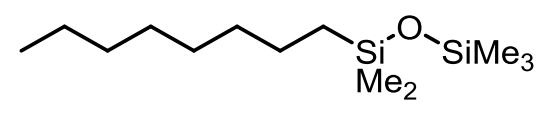

1,1,1,3,3-Pentamethyl-3-octyldisiloxane.

Prepared according to general method $\mathrm{A}$, using ( $\left.{ }^{\mathrm{TF}} \mathrm{APDI}\right) \mathrm{Co}(2-\mathrm{EH})_{2}(6$ $\mathrm{mg}, 0.01 \mathrm{mmol}$ ), 1-octene (112 mg, $1.00 \mathrm{mmol}$ ), and 1,1,1,3,3-pentamethyldisiloxane (148 mg, $1.00 \mathrm{mmol})$. The product was isolated as a clear, colorless oil $(249 \mathrm{mg}, 96 \%) .{ }^{1} \mathrm{H}$ NMR $(500$ $\left.\mathrm{MHz}, \mathrm{CDCl}_{3}\right): \delta=1.34-1.22(12 \mathrm{H}, \mathrm{m}), 0.88(3 \mathrm{H}, \mathrm{t}, J=7.1 \mathrm{~Hz}), 0.53-0.47(2 \mathrm{H}, \mathrm{m}), 0.06(9 \mathrm{H}, \mathrm{s})$, $0.03(6 \mathrm{H}, \mathrm{s}) .{ }^{13} \mathrm{C} \operatorname{NMR}\left(125 \mathrm{MHz}_{\mathrm{CDCl}}\right): \delta=33.6,32.1,29.5,29.4,23.4,22.9,18.5,14.3,2.1$, 0.5. All spectra are in accordance with the literature. ${ }^{5}$

$\mathrm{SiEt}_{3}$ Triethyl(octyl)silane. Prepared according to general method A with slight modification, using ( $\left.{ }^{\mathrm{TF}} \mathrm{APDI}\right) \mathrm{Co}(2-\mathrm{EH})_{2}(6 \mathrm{mg}, 0.01 \mathrm{mmol}), 1$-octene $(112 \mathrm{mg}, 1.00 \mathrm{mmol})$, and triethylsilane $(116 \mathrm{mg}, 1.00 \mathrm{mmol})$. The sealed vial was heated to $80{ }^{\circ} \mathrm{C}$ for one hour. The product was isolated as a 44:56 mixture of the title compound and dehydrogenative silylation product. Clear, colorless oil (147 mg, 64\%). All spectra are in accordance with the literature. ${ }^{4,6}$ 


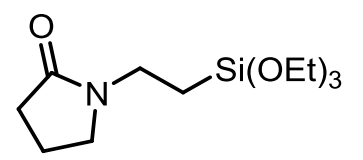

1-(2-(Triethoxysilyl)ethyl)pyrrolidin-2-one. Prepared according to general method C, using ( $\left.{ }^{\mathrm{TF}} \mathrm{APDI}\right) \mathrm{Co}(2-\mathrm{EH})_{2}(0.019 \mathrm{M}$ solution in toluene, $0.263 \mathrm{~mL}, 0.005 \mathrm{mmol})$, triethoxysilane $(329 \mathrm{mg}, 2.00 \mathrm{mmol})$, and 1-vinylpyrrolidin-2-one (0.214 $\mathrm{mL}, 2.00 \mathrm{mmol})$. The product was isolated as a clear, colorless oil $(460 \mathrm{mg}, 84 \%) .{ }^{1} \mathrm{H}$ NMR $\left(500 \mathrm{MHz}, \mathrm{CDCl}_{3}\right): \delta=3.82(6 \mathrm{H}, \mathrm{q}, J=7.0 \mathrm{~Hz}), 3.42-3.35(4 \mathrm{H}, \mathrm{m}), 2.35(2 \mathrm{H}, \mathrm{t}, J=8.2 \mathrm{~Hz}), 1.99$ (2H, app. pent., $J=7.6 \mathrm{~Hz}), 1.22(9 \mathrm{H}, \mathrm{t}, J=7.0 \mathrm{~Hz}), 0.93-0.88(2 \mathrm{H}, \mathrm{m}) .{ }^{13} \mathrm{C} \mathrm{NMR}(125 \mathrm{MHz}$, $\left.\mathrm{CDCl}_{3}\right): \delta=174.5,58.6,46.5,37.7,31.4,18.4,18.0,9.9$.

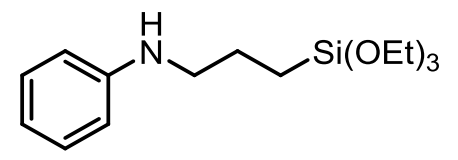

$\mathrm{N}$-(3-(triethoxysilyl)propyl)aniline. Prepared according to general method C, using ( $\left.{ }^{\mathrm{TF}} \mathrm{APDI}\right) \mathrm{Co}(2-\mathrm{EH})_{2}(0.019 \mathrm{M}$ solution in toluene, $0.263 \mathrm{~mL}, 0.005 \mathrm{mmol})$, triethoxysilane $(329 \mathrm{mg}, 2.00 \mathrm{mmol})$, and $\mathrm{N}$-allylaniline $(0.271 \mathrm{~mL}, 2.00$ $\mathrm{mmol})$. The product was isolated as a clear, colorless oil (579 mg, 97\%). ${ }^{1} \mathrm{H} \mathrm{NMR}(500 \mathrm{MHz}$, $\left.\mathrm{CDCl}_{3}\right): \delta=7.17(2 \mathrm{H}, \mathrm{dd}, J=8.5,7.4 \mathrm{~Hz}), 6.68(1 \mathrm{H}, \mathrm{t}, J=7.3 \mathrm{~Hz}), 6.61(2 \mathrm{H}, \mathrm{d}, J=7.7 \mathrm{~Hz}), 3.92$ $(1 \mathrm{H}, \mathrm{br}$ s), $3.83(6 \mathrm{H}, \mathrm{q}, J=7.0 \mathrm{~Hz}), 3.13(2 \mathrm{H}, \mathrm{t}, J=7.1 \mathrm{~Hz}), 1.75(2 \mathrm{H}$, app. pent., $J=7.2 \mathrm{~Hz})$, $1.23(9 \mathrm{H}, \mathrm{t}, J=7.0 \mathrm{~Hz}), 0.74-0.69(2 \mathrm{H}, \mathrm{m}) .{ }^{13} \mathrm{C} \mathrm{NMR}\left(125 \mathrm{MHz}, \mathrm{CDCl}_{3}\right): \delta=148.4,129.3$, 117.2, 112.9, 58.6, 46.6, 22.9, 18.5, 8.0. HRMS-(ESI-TOF) for $\mathrm{C}_{15} \mathrm{H}_{28} \mathrm{NO}_{3} \mathrm{Si}[\mathrm{M}+\mathrm{H}]^{+}$: calculated: 298.1833, found: 298.1836 .

$\mathrm{Me}_{2} \mathrm{~N} \sim \mathrm{Si}(\mathrm{OEt})_{3} \quad \mathrm{~N}, \mathrm{~N}$-dimethyl-3-(triethoxysilyl)propan-1-amine. Prepared according to general method $\mathrm{C}$, using $\left({ }^{\mathrm{TF}} \mathrm{APDI}\right) \mathrm{Co}(2-\mathrm{EH})_{2}(0.019 \mathrm{M}$ solution in toluene, $0.526 \mathrm{~mL}, 0.01$ $\mathrm{mmol})$, triethoxysilane (329 mg, $2.00 \mathrm{mmol})$, and $\mathrm{N}, \mathrm{N}$-dimethylprop-2-en-1-amine $(0.237 \mathrm{mg}$, $2.00 \mathrm{mmol})$. The product was isolated as a clear, colorless oil $(367 \mathrm{mg}, 74 \%) .{ }^{1} \mathrm{H}$ NMR (500 $\left.\mathrm{MHz}, \mathrm{CDCl}_{3}\right): \delta=3.81(6 \mathrm{H}, \mathrm{q}, J=7.0 \mathrm{~Hz}), 2.26(2 \mathrm{H}, \mathrm{t}, J=7.5 \mathrm{~Hz}), 2.21(6 \mathrm{H}, \mathrm{s}), 1.62-1.53(2 \mathrm{H}$, $\mathrm{m}), 1.21(9 \mathrm{H}, \mathrm{t}, J=7.0 \mathrm{~Hz}), 0.64-0.57(2 \mathrm{H}, \mathrm{m}) .{ }^{13} \mathrm{C} \mathrm{NMR}\left(125 \mathrm{MHz}, \mathrm{CDCl}_{3}\right): \delta=62.9,58.5$, 45.6, 21.1, 18.4, 8.1. All spectra are in accordance with the literature. ${ }^{4}$ 


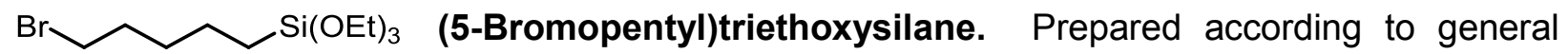
method $\mathrm{C}$ with slight modification, using ( $\left.{ }^{\mathrm{TF}} \mathrm{APDI}\right) \mathrm{Co}(2-\mathrm{EH})_{2}(6 \mathrm{mg}, 0.01 \mathrm{mmol})$, triethoxysilane (164 mg, $1.00 \mathrm{mmol})$, and 5-bromopent-1-ene $(0.118 \mathrm{~mL}, 1.00 \mathrm{mmol})$. The reaction was stirred for 5 hours at room temperature. The product was isolated as a clear, colorless oil (196 mg, 63\%). ${ }^{1} \mathrm{H}$ NMR (500 MHz, $\left.\mathrm{CDCl}_{3}\right): \delta=3.81(6 \mathrm{H}, \mathrm{q}, J=7.0 \mathrm{~Hz}), 3.40(2 \mathrm{H}, \mathrm{t}, J=6.9 \mathrm{~Hz}), 1.86$ (2H, app. pent., $J=7.0 \mathrm{~Hz}), 1.50-1.40(4 \mathrm{H}, \mathrm{m}), 1.22(9 \mathrm{H}, \mathrm{t}, J=7.0 \mathrm{~Hz}), 0.67-0.59(2 \mathrm{H}, \mathrm{m}) .{ }^{13} \mathrm{C}$ $\operatorname{NMR}\left(125 \mathrm{MHz}, \mathrm{CDCl}_{3}\right): \delta=58.5,34.1,32.6,31.7,22.2,18.5,10.4$. All spectra are in accordance with the literature. ${ }^{7}$

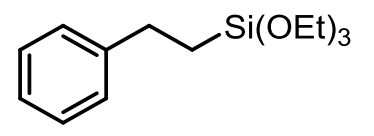

Triethoxy(phenethyl)silane. Prepared according to general method B, using ( $\left.{ }^{\mathrm{TF}} \mathrm{APDI}\right) \mathrm{Co}(2-\mathrm{EH})_{2}(0.026 \mathrm{M}$ solution in toluene, $0.190 \mathrm{~mL}, 0.005$ $\mathrm{mmol})$, triethoxysilane $(329 \mathrm{mg}, 2.00 \mathrm{mmol})$, and styrene $(208 \mathrm{mg}, 2.00 \mathrm{mmol})$. The product was isolated as a clear, colorless oil (543 mg, 100\%). ${ }^{1} \mathrm{H}$ NMR $\left(500 \mathrm{MHz}, \mathrm{CDCl}_{3}\right): \delta=7.28(2 \mathrm{H}$, app. t, $J=7.5 \mathrm{~Hz}), 7.22(2 \mathrm{H}, \mathrm{d}, J=7.2 \mathrm{~Hz}), 7.17(1 \mathrm{H}, \mathrm{t}, J=7.3 \mathrm{~Hz}), 3.83(6 \mathrm{H}, \mathrm{q}, J=7.0 \mathrm{~Hz})$, 2.77-2.72 $(2 \mathrm{H}, \mathrm{m}), 1.24(9 \mathrm{H}, \mathrm{t}, J=7.0 \mathrm{~Hz}), 1.03-0.98(2 \mathrm{H}, \mathrm{m}) .{ }^{13} \mathrm{C} \mathrm{NMR}\left(125 \mathrm{MHz}, \mathrm{CDCl}_{3}\right): \delta=$ $144.7,128.4,127.9,125.8,58.5,29.0,18.5,12.6$. All spectra are in accordance with the literature. $^{4}$

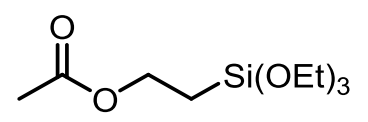

2-(Triethoxysilyl)ethyl acetate. Prepared according to general method

$B$ with slight modification, using ( $\left.{ }^{\mathrm{TF}} \mathrm{APDI}\right) \mathrm{Co}(2-\mathrm{EH})_{2}(0.019 \mathrm{M}$ solution in toluene, $0.262 \mathrm{~mL}, 0.005 \mathrm{mmol})$, triethoxysilane $(329 \mathrm{mg}, 2.00 \mathrm{mmol})$, and vinyl acetate (172 $\mathrm{mg}, 2.00 \mathrm{mmol})$. The reaction was stirred for 5 hours at room temperature. The product was isolated as a clear, colorless oil $(432 \mathrm{mg}, 86 \%) .{ }^{1} \mathrm{H} \mathrm{NMR}\left(300 \mathrm{MHz}, \mathrm{CDCl}_{3}\right): \delta=4.21-4.16(2 \mathrm{H}$, m), $3.81(6 \mathrm{H}, \mathrm{q}, J=7.0 \mathrm{~Hz}), 2.02(3 \mathrm{H}, \mathrm{s}), 1.21(9 \mathrm{H}, \mathrm{t}, J=7.0 \mathrm{~Hz}), 1.12-1.06(2 \mathrm{H}, \mathrm{m}) .{ }^{13} \mathrm{C} \mathrm{NMR}$ $\left(125 \mathrm{MHz}, \mathrm{CDCl}_{3}\right): \delta=171.2,61.3,58.6,21.3,18.4,12.1$. HRMS-(ESI-TOF) for $\mathrm{C}_{10} \mathrm{H}_{22} \mathrm{NaO}_{5} \mathrm{Si}$ $[\mathrm{M}+\mathrm{Na}]^{+}:$calculated: 273.1129, found: 273.1138 . 


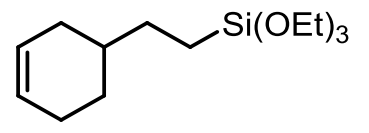

(2-(Cyclohex-3-en-1-yl)ethyl)triethoxysilane. Prepared according to general method $\mathrm{B}$, using $\left({ }^{\mathrm{TF}} \mathrm{APDI}\right) \mathrm{Co}(2-\mathrm{EH})_{2}(0.019 \mathrm{M}$ solution in toluene, $0.263 \mathrm{~mL}, 0.005 \mathrm{mmol})$, triethoxysilane (329 mg, $2.00 \mathrm{mmol})$, and 4-vinylcyclohexene (216 $\mathrm{mg}$, $2.00 \mathrm{mmol})$. The product was isolated as a clear, colorless oil (530 mg, 97\%). ${ }^{1} \mathrm{H}$ NMR (500 $\left.\mathrm{MHz}, \mathrm{CDCl}_{3}\right): \delta=5.67-5.61(2 \mathrm{H}, \mathrm{m}), 3.82(6 \mathrm{H}, \mathrm{q}, J=7.0 \mathrm{~Hz}), 2.15-2.07(1 \mathrm{H}, \mathrm{m}), 2.06-1.98(2 \mathrm{H}$, m), 1.79-1.71 $(1 \mathrm{H}, \mathrm{m}), 1.66-1.56(1 \mathrm{H}, \mathrm{m}), 1.50-1.41(1 \mathrm{H}, \mathrm{m}), 1.40-1.33(2 \mathrm{H}, \mathrm{m}), 1.23(9 \mathrm{H}, \mathrm{t}, J=$ 7.0 Hz), 1.20-1.13 (1H, m), 0.68-0.62 (2H, m). ${ }^{13} \mathrm{C}$ NMR (125 MHz, $\left.\mathrm{CDCl}_{3}\right): \delta=127.2,126.8$, 58.5, 36.4, 31.6, 29.5, 28.6, 25.5, 18.5, 7.6. HRMS-(ESI-TOF) for $\mathrm{C}_{12} \mathrm{H}_{23} \mathrm{O}_{2} \mathrm{Si}\left[\mathrm{M}+\mathrm{H}-\mathrm{C}_{2} \mathrm{H}_{5} \mathrm{OH}\right]^{+}$: calculated: 227.1462 , found: 227.1458 .

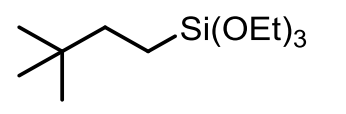

(3,3-Dimethylbutyl)triethoxysilane. Prepared according to general method $B$ with slight modification, using ( $\left.{ }^{\mathrm{TF}} \mathrm{APDI}\right) \mathrm{Co}(2-\mathrm{EH})_{2}(0.025 \mathrm{M}$ solution in toluene, $0.400 \mathrm{~mL}, 0.01 \mathrm{mmol})$, triethoxysilane $(329 \mathrm{mg}, 2.00 \mathrm{mmol})$, and tertbutylethylene $(168 \mathrm{mg}, 2.00 \mathrm{mmol})$. The reaction was stirred at room temperature for 24 hours. The product was isolated as a clear, colorless oil $(430 \mathrm{mg}, 87 \%) .{ }^{1} \mathrm{H} \mathrm{NMR}\left(500 \mathrm{MHz}, \mathrm{CDCl}_{3}\right): \delta$ $=3.82(6 \mathrm{H}, \mathrm{q}, J=7.0 \mathrm{~Hz}), 1.30-1.25(2 \mathrm{H}, \mathrm{m}), 1.23(9 \mathrm{H}, \mathrm{t}, J=7.0 \mathrm{~Hz}), 0.85(9 \mathrm{H}, \mathrm{s}), 0.60-0.54$ $(2 \mathrm{H}, \mathrm{m}) .{ }^{13} \mathrm{C}$ NMR $\left(125 \mathrm{MHz}, \mathrm{CDCl}_{3}\right): \delta=58.5,36.5,31.1,28.8,18.5,4.8$. All spectra are in accordance with the literature. ${ }^{8}$

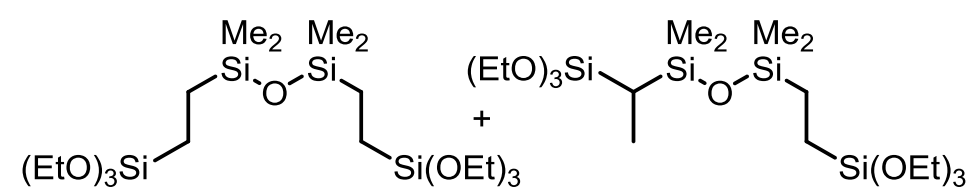

$(59: 41)$
4,4,12,12-Tetraethoxy-7,7,9,9tetramethyl-3,8,13-trioxa-4,7,9,12tetrasilapentadecane. Prepared

according to general method $\mathrm{B}$, using ( $\left.{ }^{\mathrm{TF}} \mathrm{APDI}\right) \mathrm{Co}(2-\mathrm{EH})_{2}(0.019 \mathrm{M}$ solution in toluene, 0.103 $\mathrm{mL}, \quad 0.002 \mathrm{mmol})$, 1,1,3,3-tetramethyl-1,3-divinyldisiloxane (186 mg, $1.00 \mathrm{mmol})$, and triethoxysilane $(329 \mathrm{mg}, 2.00 \mathrm{mmol})$. Caution! Silane addition produces an exothermeric 
reaction and should be performed carefully. The product was isolated as a 41:59 mixture of Markovnikov and anti-Markovnikov products as shown above. Clear, colorless oil (497 mg, 97\%). ${ }^{1} \mathrm{H}$ NMR $\left(500 \mathrm{MHz}, \mathrm{CDCl}_{3}\right):$ (major) $\delta=3.82(12 \mathrm{H}, \mathrm{q}, J=7.0 \mathrm{~Hz}), 1.23(18 \mathrm{H}, \mathrm{t}, J=7.0$ $\mathrm{Hz}), 0.58-0.49(8 \mathrm{H}, \mathrm{m}), 0.04(12 \mathrm{H}, \mathrm{s}) ;($ minor $) \delta=3.82(6 \mathrm{H}, \mathrm{q}, J=7.0 \mathrm{~Hz}), 3.81(6 \mathrm{H}, \mathrm{q}, J=7.0$ $\mathrm{Hz}), 1.23(9 \mathrm{H}, \mathrm{t}, J=7.0 \mathrm{~Hz}), 1.21(9 \mathrm{H}, \mathrm{t}, J=7.0 \mathrm{~Hz}), 1.07(3 \mathrm{H}, \mathrm{d}, J=7.6 \mathrm{~Hz}), 0.58-0.49(4 \mathrm{H}, \mathrm{m})$, 0.13-0.11 (1H, m), $0.11(3 \mathrm{H}, \mathrm{s}), 0.10(3 \mathrm{H}, \mathrm{s}), 0.04(6 \mathrm{H}, \mathrm{s}) \cdot{ }^{13} \mathrm{C}$ NMR $\left(125 \mathrm{MHz}, \mathrm{CDCl}_{3}\right)$ : (both products, 4 overlapping signals) $\delta=58.52,58.45,18.5,9.4,9.3,7.9,6.2,2.0,1.9,1.3,0.2$, 0.27, -0.32. HRMS-(ESI-TOF) for $\mathrm{C}_{20} \mathrm{H}_{50} \mathrm{KO}_{7} \mathrm{Si}_{4}[\mathrm{M}+\mathrm{K}]^{+}$: calculated: 553.2265, found: 553.2258.

$\sim^{\mathrm{O}} \sim_{(\mathrm{OEt})_{3}}$ Triethoxy(3-ethoxypropyl)silane. Prepared according to general method $\mathrm{C}$, using ( $\left.{ }^{\mathrm{TF}} \mathrm{APDI}\right) \mathrm{Co}(2-\mathrm{EH})_{2}(0.20 \mathrm{M}$ solution in toluene, $0.494 \mathrm{~mL}, 0.01 \mathrm{mmol})$, triethoxysilane $(329 \mathrm{mg}, 2.00 \mathrm{mmol})$, and allyl ethylether $(0.227 \mathrm{~mL}, 2.00 \mathrm{mmol})$. The product was isolated as a clear, colorless oil $(432 \mathrm{mg}, 86 \%) .{ }^{1} \mathrm{H} \mathrm{NMR}\left(500 \mathrm{MHz}, \mathrm{CDCl}_{3}\right): \delta=3.81(6 \mathrm{H}$, $\mathrm{q}, J=7.0 \mathrm{~Hz}), 3.46(2 \mathrm{H}, \mathrm{q}, J=7.0 \mathrm{~Hz}), 3.38(2 \mathrm{H}, \mathrm{t}, J=7.0 \mathrm{~Hz}), 1.73-1.63(2 \mathrm{H}, \mathrm{m}), 1.22(9 \mathrm{H}, \mathrm{t}, J$ $=7.0 \mathrm{~Hz}), 0.67-0.61(2 \mathrm{H}, \mathrm{m}) .{ }^{13} \mathrm{C} \operatorname{NMR}\left(125 \mathrm{MHz}, \mathrm{CDCl}_{3}\right): \delta=73.1,66.1,58.5,23.2,18.4,15.4$, 6.6. HRMS-(ESI-TOF) for $\mathrm{C}_{11} \mathrm{H}_{26} \mathrm{NaO}_{4} \mathrm{Si}[\mathrm{M}+\mathrm{Na}]^{+}$: calculated: 273.1493 , found: 273.1496 .

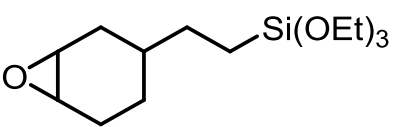

(2-(7-oxabicyclo[4.1.0]heptan-3-yl)ethyl)triethoxysilane. Prepared according to general method $\mathrm{B}$, using ( $\left.{ }^{\mathrm{TF}} \mathrm{APDI}\right) \mathrm{Co}(2-\mathrm{EH})_{2}(0.019 \mathrm{M}$ solution in toluene, $0.262 \mathrm{~mL}, 0.005 \mathrm{mmol}$ ), triethoxysilane (329 mg, $2.00 \mathrm{mmol}$ ), and 4vinylcyclohexene-1,2-oxide (mixture of stereoisomers) (248 $\mathrm{mg}, 2.00 \mathrm{mmol}$ ). The product was isolated as a clear, colorless oil (553 mg, 96\%). ${ }^{1} \mathrm{H}$ NMR (500 MHz, $\mathrm{CDCl}_{3}$ ): (mixture of 2 diastereomers, approx.. 40:60 ratio) $\delta=3.80(6 \mathrm{H}, \mathrm{q}, J=7.0 \mathrm{~Hz}), 3.20-3.09(2 \mathrm{H}, \mathrm{m}), 2.21-2.10$ $(1 \mathrm{H}, \mathrm{m}), 2.09-2.01(0.4 \mathrm{H}, \mathrm{m}), 2.01-1.94(0.6 \mathrm{H}, \mathrm{m}), 1.85-1.76(0.6 \mathrm{H}, \mathrm{m}), 1.73-1.64(0.6 \mathrm{H}, \mathrm{m})$, 1.54-1.46 (0.6H, m), 1.43-1.30 (2H, m), 1.30-1.24 (2.4H, m), $1.21(9 \mathrm{H}, \mathrm{t}, J=7.0 \mathrm{~Hz}), 1.18-1.10$ $(0.6 \mathrm{H}, \mathrm{m}), 1.10-1.00(0.4 \mathrm{H}, \mathrm{m}), 0.92-0.81(0.8 \mathrm{H}, \mathrm{m}), 0.62-0.52(2 \mathrm{H}, \mathrm{m}) .{ }^{13} \mathrm{C} \mathrm{NMR}(125 \mathrm{MHz}$, 
$\mathrm{CDCl}_{3}$ ): (both diastereomers, 2 overlapping signals) $\delta=58.5,53.4,52.9,52.1,52.0,35.3,32.3$, 31.5, 30.4, 29.7, 29.1, 26.8, 25.5, 24.0, 23.7, 18.4, 7.6, 7.5. HRMS-(ESI-TOF) for $\mathrm{C}_{12} \mathrm{H}_{23} \mathrm{O}_{3} \mathrm{Si}$ $\left[\mathrm{M}+\mathrm{H}-\mathrm{C}_{2} \mathrm{H}_{5} \mathrm{OH}\right]^{+}$: calculated: 243.1411 , found: 243.1420 .

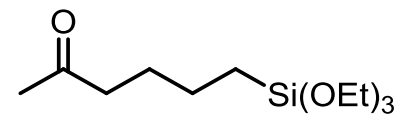

6-(triethoxysilyl)hexan-2-one. Prepared according to general method $\mathrm{B}$, using $\left({ }^{\mathrm{TF}} \mathrm{APDI}\right) \mathrm{Co}(2-\mathrm{EH})_{2}(0.020 \mathrm{M}$ solution in toluene, 0.247 $\mathrm{mL}, 0.005 \mathrm{mmol})$, triethoxysilane $(329 \mathrm{mg}, 2.00 \mathrm{mmol}$ ), and hex-5-en-2-one (196 mg, 2.00 $\mathrm{mmol})$. The product was isolated as a clear, colorless oil (487 mg, 93\%). ${ }^{1} \mathrm{H}$ NMR (500 MHz, $\left.\mathrm{CDCl}_{3}\right): \delta=3.80(6 \mathrm{H}, \mathrm{q}, J=6.9 \mathrm{~Hz}), 2.41(2 \mathrm{H}, \mathrm{t}, J=7.5 \mathrm{~Hz}), 2.12(3 \mathrm{H}, \mathrm{s}), 1.60(2 \mathrm{H}$, app. pent., $J=7.5 \mathrm{~Hz}), 1.40(2 \mathrm{H}$, app. pent., $J=7.7 \mathrm{~Hz}), 1.21(9 \mathrm{H}, \mathrm{t}, J=7.0 \mathrm{~Hz}), 0.66-0.58(2 \mathrm{H}, \mathrm{m}) .{ }^{13} \mathrm{C}$ NMR (125 MHz, $\left.\mathrm{CDCl}_{3}\right): \delta=209.3,58.5,43.6,30.0,27.4,22.6,18.4,10.4$. HRMS-(ESI-TOF) for $\mathrm{C}_{10} \mathrm{H}_{21} \mathrm{O}_{3} \mathrm{Si}\left[\mathrm{M}+\mathrm{H}-\mathrm{C}_{2} \mathrm{H}_{5} \mathrm{OH}\right]^{+}$: calculated: 217.1255, found: 217.1263.

\section{E. Procedure for 10-gram Scale Hydrosilylation of AGE}

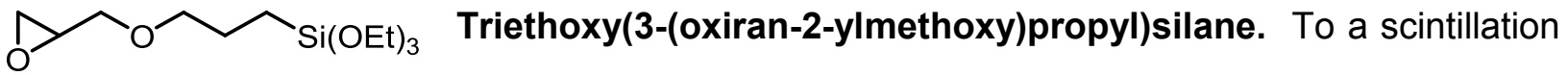
vial in a nitrogen filled glovebox was added ( $\left.{ }^{\mathrm{TF}} \mathrm{APDI}\right) \mathrm{Co}$ (2-ethylhexanoate) ${ }_{2}$ (5 mg, $\left.0.009 \mathrm{mmol}\right)$ followed by mesitylene as an internal standard $(203 \mathrm{mg}, 1.69 \mathrm{mmol})$ and triethoxysilane $(5.90 \mathrm{~g}$, $35.9 \mathrm{mmol}$ ) to give a dark green mixture. To a separate scintillation vial in the box was added allyl glycidyl ether $(4.10 \mathrm{~g}, 35.9 \mathrm{mmol})$. Both vials were sealed with septa, removed from the box and placed under argon. The mixture of catalyst and silane was then transferred via syringe to an argon filled $50 \mathrm{~mL}$ three neck round-bottomed flask equipped with stir bar, reflux condenser, temperature probe and septum. Allyl glycidyl ether was then taken up in a syringe and added to the stirring catalyst/silane mixture at $30{ }^{\circ} \mathrm{C}$ over a period of 19 minutes. During 
the course of addition, the reaction gently exothermed to $40{ }^{\circ} \mathrm{C}$, and was maintained between 40 and $45{ }^{\circ} \mathrm{C}$ for an additional 20 minutes after full addition. The reaction was monitored by taking aliquots which were analyzed by both ${ }^{1} \mathrm{H}$ NMR and GC. The product distribution was determined by ${ }^{1} \mathrm{H}$ NMR analysis. ${ }^{1} \mathrm{H}$ NMR $\left(500 \mathrm{MHz}, \mathrm{CDCl}_{3}\right): \delta=3.81(6 \mathrm{H}, \mathrm{q}, \mathrm{J}=7.0 \mathrm{~Hz}), 3.70$ $(1 \mathrm{H}, \mathrm{dd}, J=11.5,3.1 \mathrm{~Hz}), 3.51-3.41(2 \mathrm{H}, \mathrm{m}), 3.38(1 \mathrm{H}, \mathrm{dd}, J=11.5,5.8 \mathrm{~Hz}), 3.14(1 \mathrm{H}$, app. dtd, $J=6.9,3.0,3.0,2.8 \mathrm{~Hz}), 2.79(1 \mathrm{H}$, app. $\mathrm{t}, J=4.3 \mathrm{~Hz}), 2.60(1 \mathrm{H}, \mathrm{dd}, J=5.0,2.7 \mathrm{~Hz}), 1.74-1.66$ $(2 \mathrm{H}, \mathrm{m}), 1.22(9 \mathrm{H}, \mathrm{t}, J=7.0 \mathrm{~Hz}), 0.68-0.60(2 \mathrm{H}, \mathrm{m}) .{ }^{13} \mathrm{C} \mathrm{NMR}\left(125 \mathrm{MHz}, \mathrm{CDCl}_{3}\right): \delta=73.9,71.5$, 58.5, 51.0, 44.5, 23.1, 18.4, 6.6. HRMS-(ESI-TOF) for $\mathrm{C}_{12} \mathrm{H}_{26} \mathrm{NaO}_{5} \mathrm{Si}[\mathrm{M}+\mathrm{Na}]^{+}$: calculated: 301.1442, found: 301.1447.

\section{F. Crosslinking of Silicone Fluids}

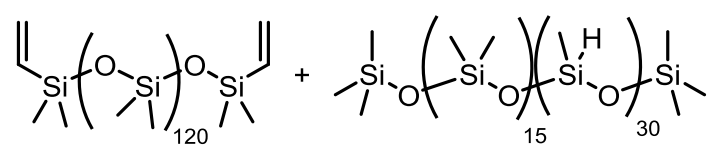

(SL6100) (olefin:Si-H = 1:2) (SL6020)

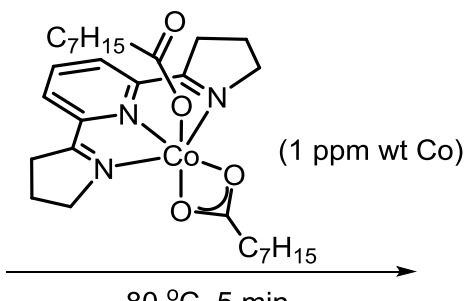

$80^{\circ} \mathrm{C}, 5 \mathrm{~min}$
Crosslinked Silicone $\mathrm{Gel}$

To a scintillation vial in a nitrogen filled glovebox was added olefin fluid SL6100 (2.00 g) followed by SL6020 (0.088 g) (1:2 olefin:Si-H ratio). The fluids were thoroughly mixed to give a clear, colorless solution. ( $\left.{ }^{\mathrm{TF}} \mathrm{APDI}\right) \mathrm{Co}(2 \text {-ethylhexanoate })_{2}$ was then added as a solution in toluene $(10 \mu \mathrm{L}, 0.0036 \mathrm{M})[2 \mathrm{ppm}$ wt Co] which immediately dispersed into the fluid mixture. The vial was sealed with a cap, removed from the box and heated to $80 \mathrm{C}$ in an oil bath. After 5 minutes, gel formation occurred and the reaction was allowed to stand at room temperature for an additional 12 hours. The resulting clear, colorless gel was opened to air and broken up with a spatula to assess the color and consistency of the product obtained. The procedure was 
repeated with higher catalyst loadings (50 ppm, 10 ppm, and 2 ppm wt. Co) in the same manner to produce the gels shown in Scheme 1.

\section{G. Air Exposure Experiments}

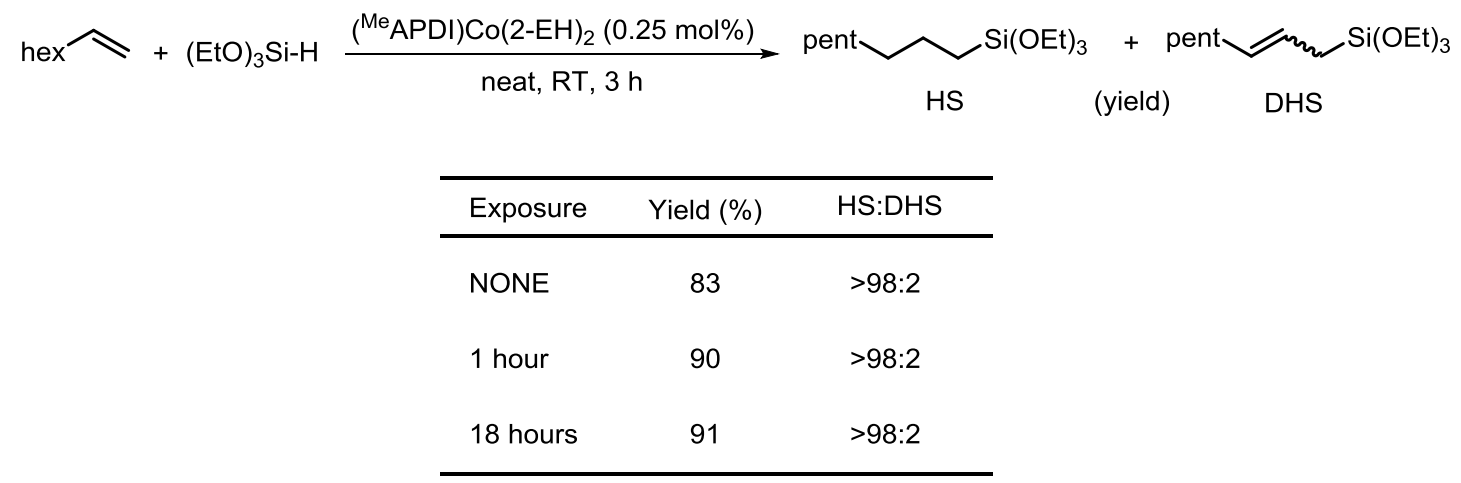

$\left({ }^{\mathrm{Me}} \mathrm{APDI}\right) \mathrm{Co}(2-\mathrm{EH})_{2}(11 \mathrm{mg}, 0.021 \mathrm{mmol})$ was added to each of three scintillation vials in the glovebox. Two vials were removed from the box, and left open to air on the benchtop for the indicated time ( 1 hour and 18 hours). After exposure, the vial was taken back into the box and toluene $(1.00 \mathrm{~mL})$ was added. A portion of each solution $(0.109 \mathrm{~mL}, 0.0022 \mathrm{mmol}$ (assumed if all dissolved)), was added to a scintillation vial equipped with a stir bar. The toluene was removed under reduced pressure and 1-octene $(100 \mathrm{mg}, 0.891 \mathrm{mmol}$ ) followed by triethoxysilane $(146 \mathrm{mg}, 0.891 \mathrm{mmol})$ was added. The vial was sealed with a cap, removed from the glovebox and stirred at room temperature for 3 hours. The resulting mixture was diluted with a solution of $10 \%$ diethyl ether in pentane and passed through a small column of silica gel, eluting with additional $10 \%$ ether in pentane solution $(5 \mathrm{~mL})$. The resulting clear, colorless eluent was then concentrated under a stream of nitrogen to give the isolated product which was analyzed by ${ }^{1} \mathrm{H}$ NMR. 


\section{H. Deuterium Labeling Experiment}

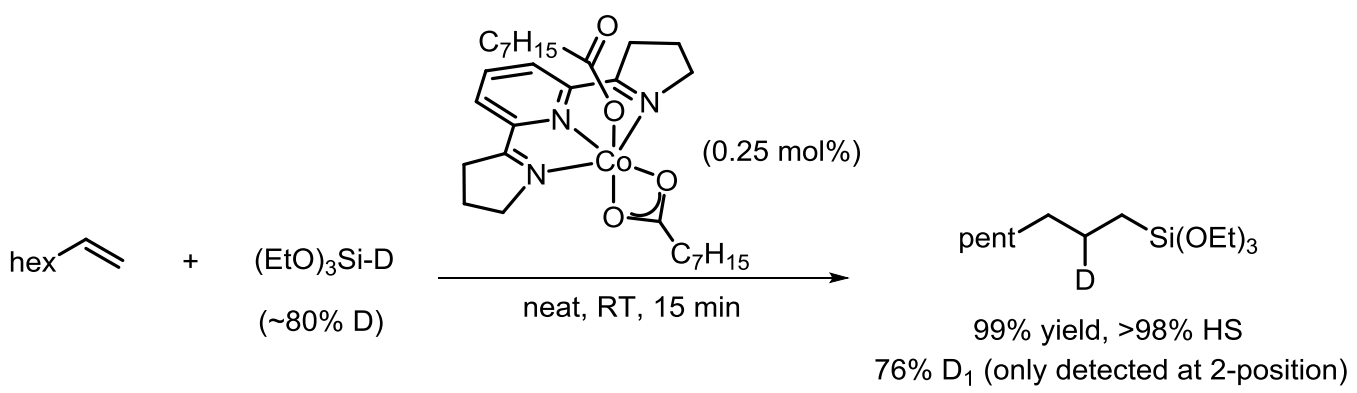

To a scintillation vial equipped with a stir bar in the glovebox was added ( $\left.{ }^{\mathrm{TF}} \mathrm{APDI}\right) \mathrm{Co}(2-\mathrm{EH})_{2}$ (0.0042 $\mathrm{M}$ solution in toluene, $0.600 \mathrm{~mL}, 0.0025 \mathrm{mmol})$. The toluene was removed under reduced pressure followed by addition of 1-ocetene $(120 \mathrm{mg}, 1.07 \mathrm{mmol})$ and triethoxysilane- $d_{1}$ $\left((\mathrm{EtO})_{3} \mathrm{Si}-\mathrm{D}\right)(177 \mathrm{mg}, 1.07 \mathrm{mmol})$ to give an olive green reaction mixture. The vial was sealed with a cap, removed from the glovebox and stirred at room temperature for 15 minutes. The cap was then removed and the resulting mixture was diluted with a solution of $10 \%$ diethyl ether in pentane and passed through a small column of silica gel, eluting with additional $10 \%$ ether in pentane solution $(5 \mathrm{~mL})$. The resulting clear, colorless eluent was concentrated under a stream of nitrogen to give the product as a clear, colorless oil $(293 \mathrm{mg}, 99 \%) .{ }^{1} \mathrm{H} \mathrm{NMR}(500 \mathrm{MHz}$, $\left.\mathrm{CDCl}_{3}\right): \delta=3.79(6 \mathrm{H}, \mathrm{q}, J=6.9 \mathrm{~Hz}), 1.42-1.33(1.24 \mathrm{H}, \mathrm{m}), 1.31-1.16(10 \mathrm{H}, \mathrm{m}), 1.20(9 \mathrm{H}, \mathrm{t}, J=$ $6.9 \mathrm{~Hz}), 0.85(3 \mathrm{H}, \mathrm{t}, J=7.1 \mathrm{~Hz}), 0.61-0.57(2 \mathrm{H}, \mathrm{m}) .{ }^{2} \mathrm{H}$ NMR $\left(76.78 \mathrm{MHz}, \mathrm{CHCl}_{3}\right): \delta=1.39$ (s). ${ }^{13} \mathrm{C}$ NMR $\left(125 \mathrm{MHz}_{\mathrm{CDCl}}\right): \delta=58.4,33.2,32.0,29.34,29.32,22.8,22.5\left(\mathrm{t}, \mathrm{J}_{\mathrm{C}-\mathrm{D}}=19.3 \mathrm{~Hz}\right)$, $18.4,14.2,10.4$ 


\section{EPR Spectra}

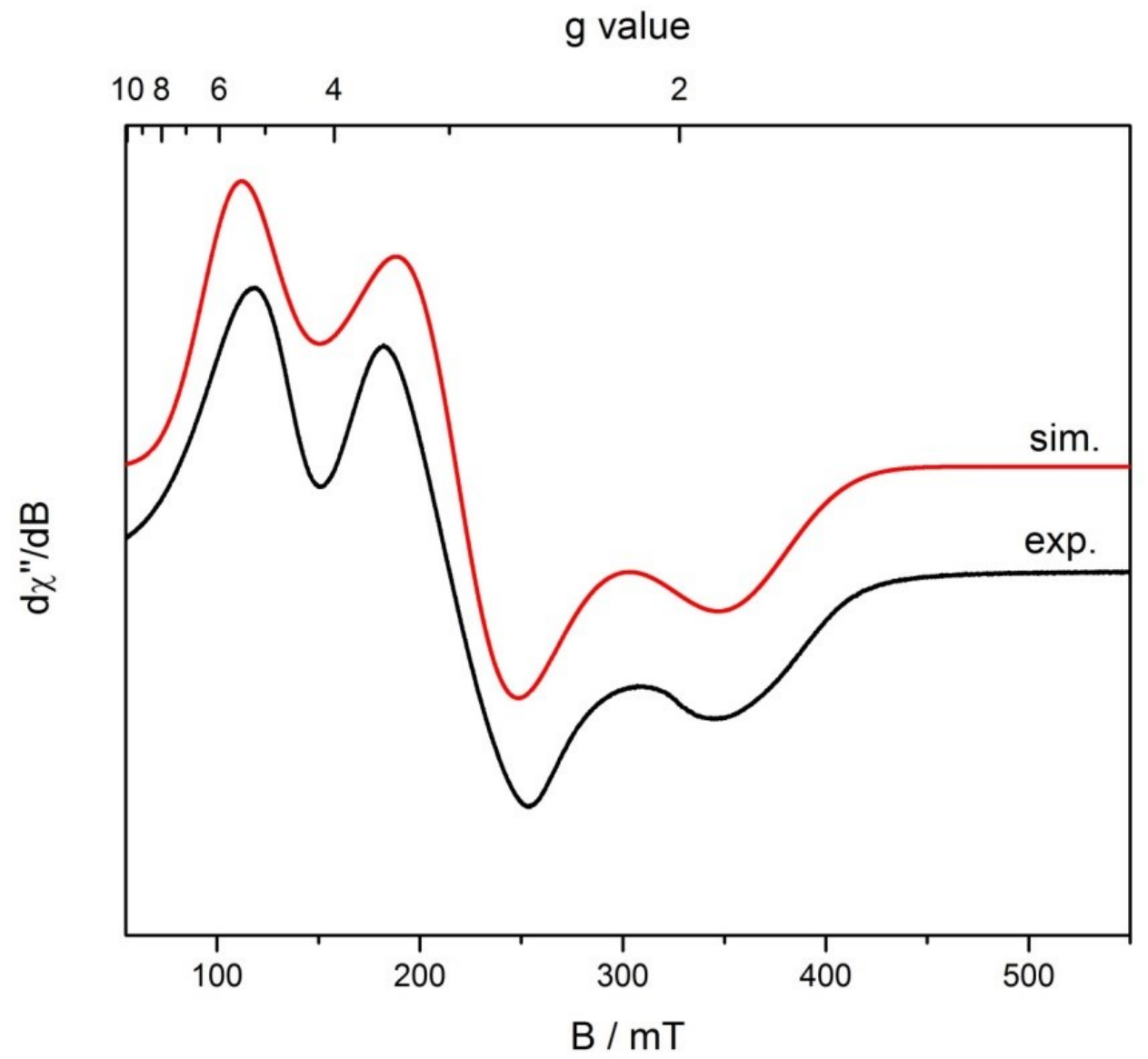

Figure S1. X-band EPR spectrum of $\left({ }^{\mathrm{Me}} \mathrm{APDI}\right) \mathrm{Co}(\mathbf{O A C})_{2}$ recorded in toluene glass at $10 \mathrm{~K}$. Microwave frequency $=9.378617 \mathrm{GHz}$, power $=2.000 \mathrm{~mW}$, modulation amplitude $=4.000 \mathrm{G}$. Spectroscopic parameters; $g_{x}=2.1, g_{y}=2.4, g_{z}=2.0, g_{\text {strain }}=(0.3,0.1,0.35)$. 


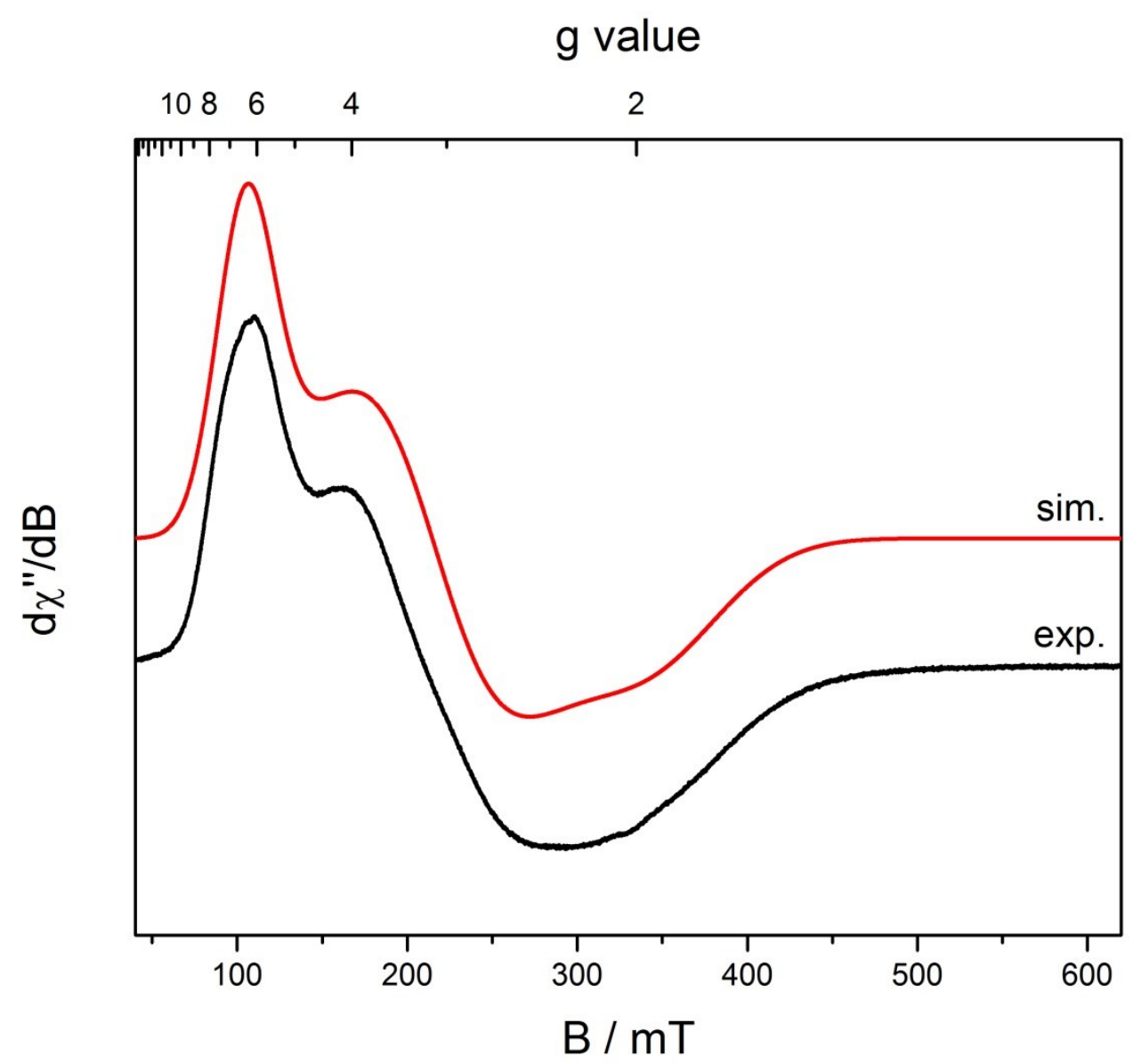

Figure S2. X-band EPR spectrum of ( $\left.{ }^{\mathrm{Me}} \mathrm{APDI}\right) \mathrm{Co}(2-\mathrm{EH})_{2}$ recorded in toluene glass at $10 \mathrm{~K}$. Microwave frequency $=9.380668 \mathrm{GHz}$, power $=0.6325 \mathrm{~mW}$, modulation amplitude $=4.000 \mathrm{G}$. Spectroscopic parameters; $g_{x}=1.96, g_{y}=2.58, g_{z}=2.04, g_{\text {strain }}=(0.75,0.1,0.5)$. 


\section{g value}

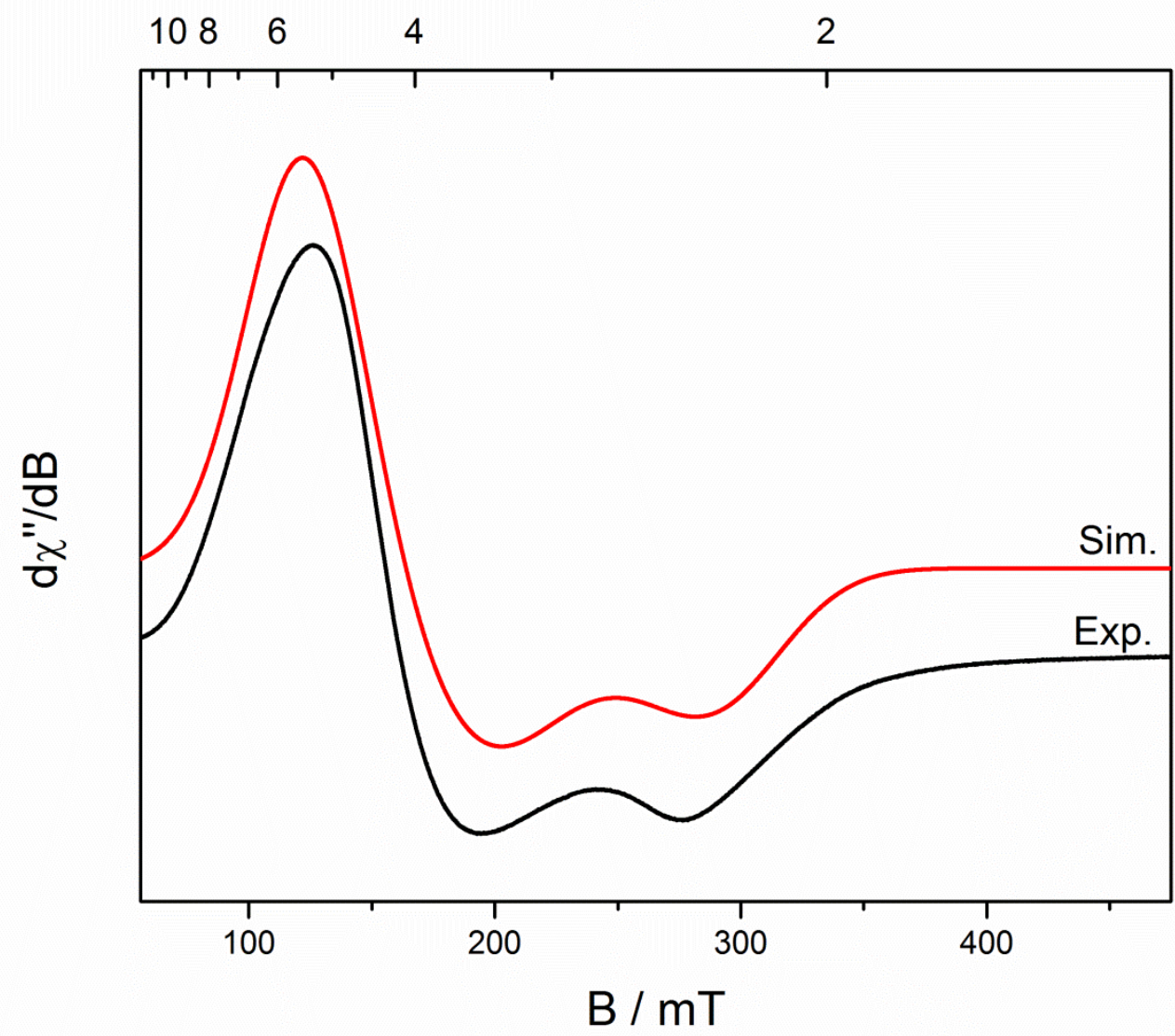

Figure S3. X-band EPR spectrum of (PyBox)Co(2-EH) ${ }_{2}$ recorded in toluene glass at $10 \mathrm{~K}$. Microwave frequency $=9.379028 \mathrm{GHz}$, power $=2.000 \mathrm{~mW}$, modulation amplitude $=4.000 \mathrm{G}$. Spectroscopic parameters; $g_{x}=2.374, g_{y}=2.363, g_{z}=2.372, g_{\text {strain }}=(0.99,0.63,0.41)$. 


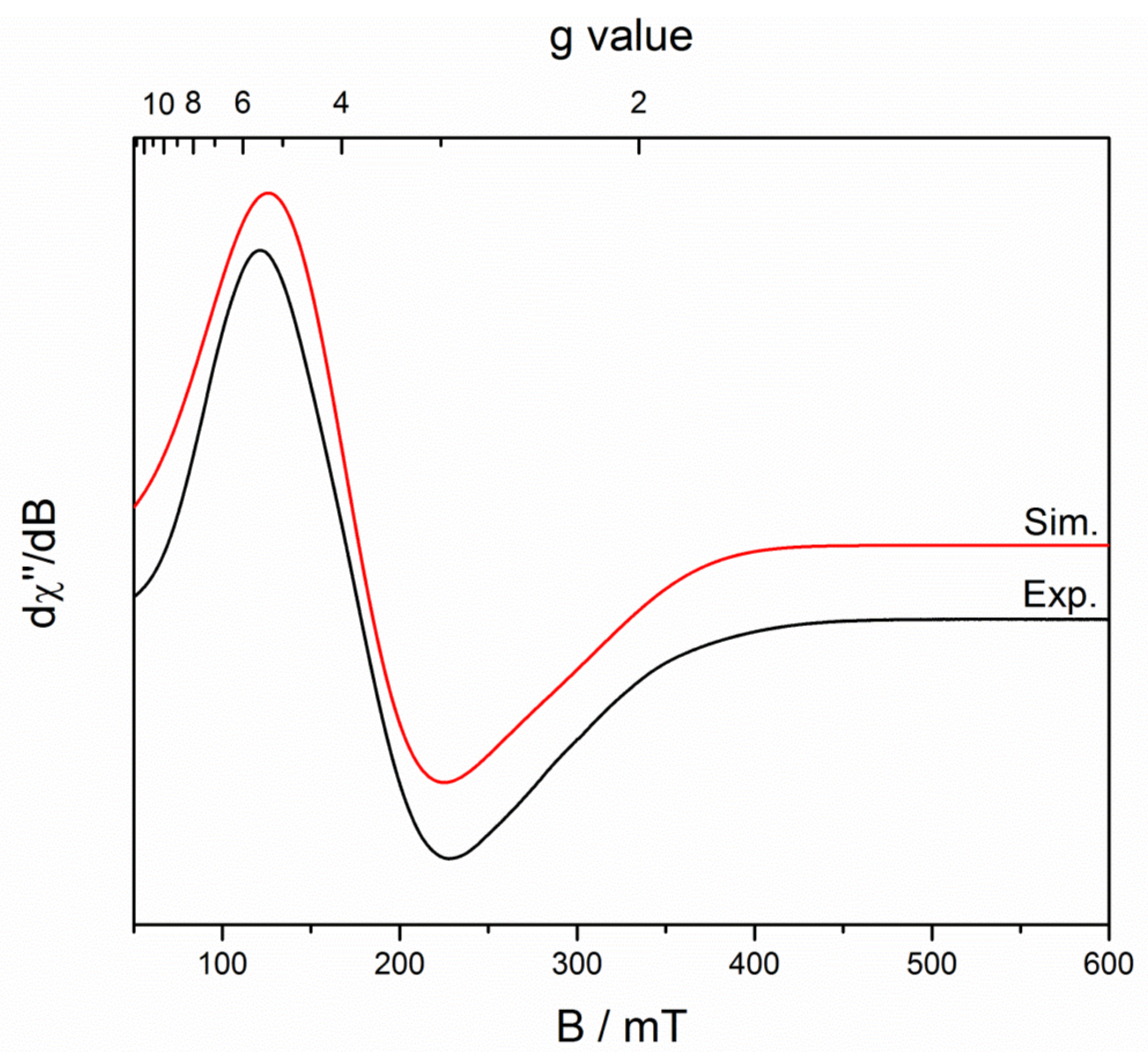

Figure S4. X-band EPR spectrum of ( $\left.{ }^{\mathrm{TF}} \mathrm{APDI}\right) \mathrm{Co}(2-\mathrm{EH})_{2}$ recorded in toluene glass at $10 \mathrm{~K}$. Microwave frequency $=9.377 \mathrm{GHz}$, power $=0.2000 \mathrm{~mW}$, modulation amplitude $=4.000 \mathrm{G}$. Spectroscopic parameters; $g_{x}=2.44, g_{y}=2.25, g_{z}=2.45, g_{\text {strain }}=(0.18,0.00,0.67)$. 


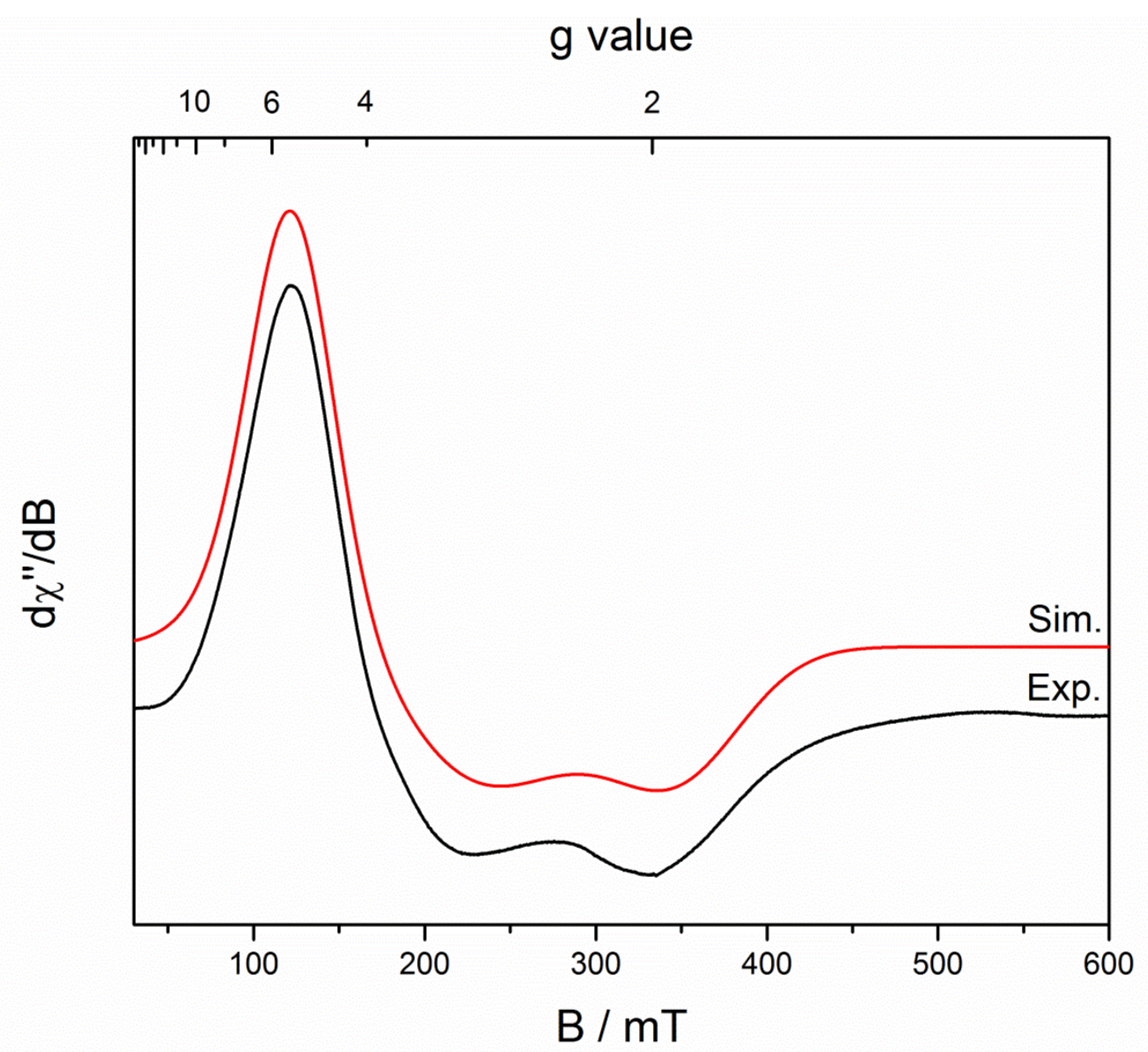

Figure S5. X-band EPR spectrum of ( $\left.{ }^{\text {Me }} \mathrm{APDI}\right) \mathrm{Co}(\mathrm{OPiv})_{2}$ recorded in toluene glass at $10 \mathrm{~K}$. Microwave frequency $=9.378434 \mathrm{GHz}$, power $=2.000 \mathrm{~mW}$, modulation amplitude $=4.000 \mathrm{G}$. Spectroscopic parameters; $g_{x}=2.21, g_{y}=2.22, g_{z}=2.00, g_{\text {strain }}=(1.39,0.01,0.39)$. 


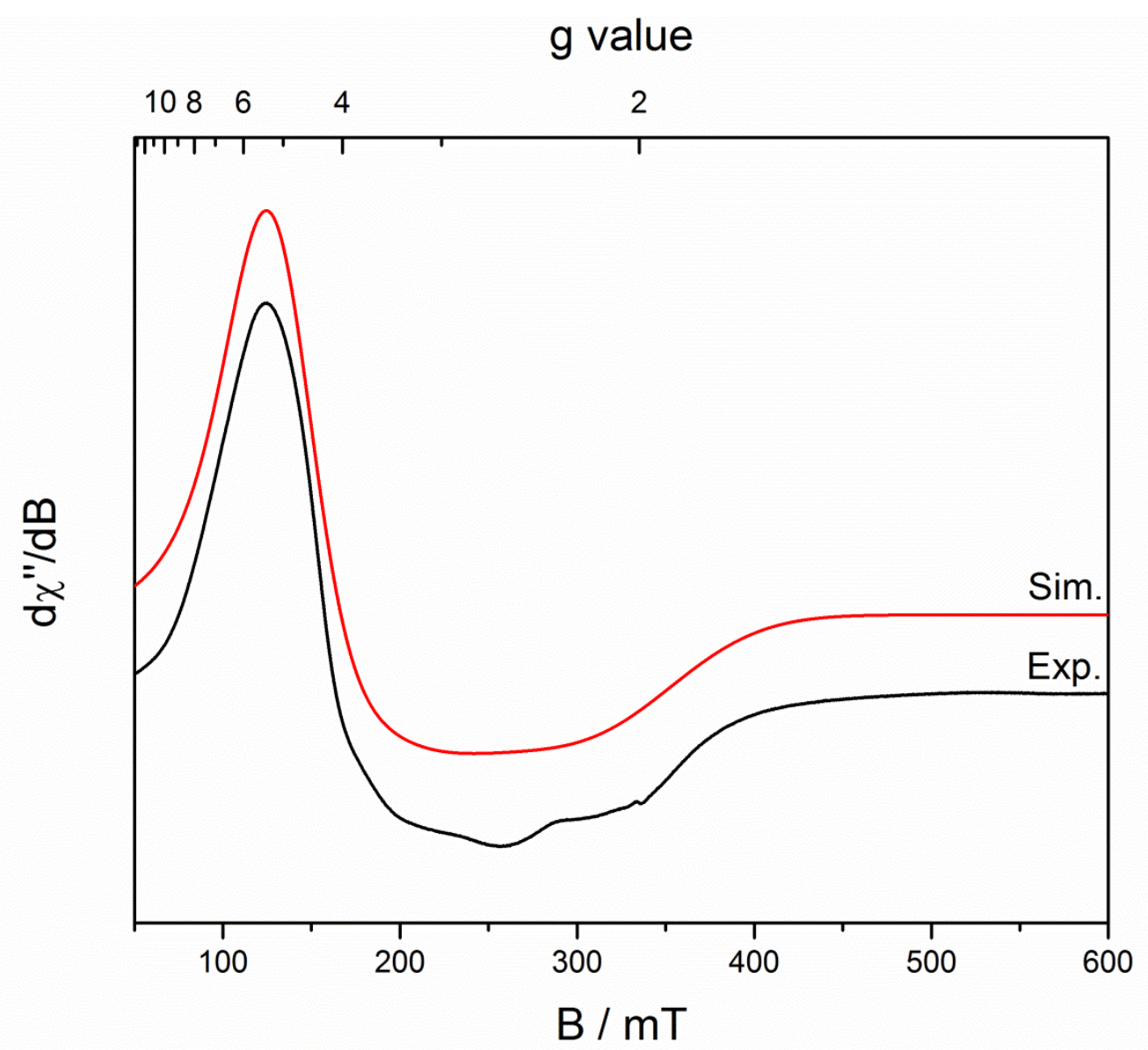

Figure S6. X-band EPR spectrum of ( ${ }^{\mathrm{TF}}$ APDI)Co(OPiv) $)_{2}$ recorded in toluene glass at $10 \mathrm{~K}$. Microwave frequency $=9.380364 \mathrm{GHz}$, power $=2.000 \mathrm{~mW}$, modulation amplitude $=4.000 \mathrm{G}$. Spectroscopic parameters; $g_{x}=2.31, g_{y}=2.15, g_{z}=2.15, g_{\text {strain }}=(1.76,0.03,0.65)$. 


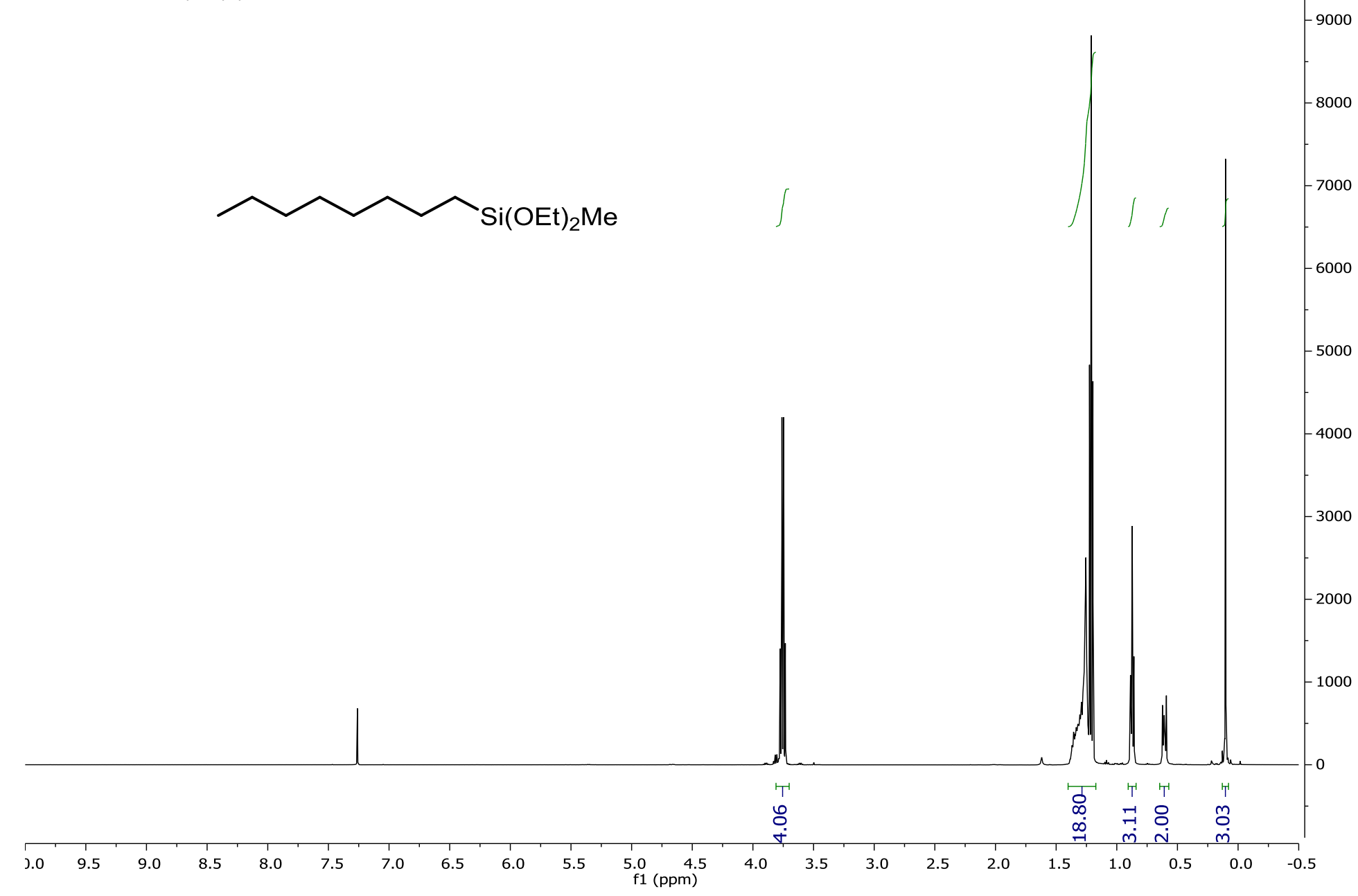

\section{A2_50-CHS-3-200.11.fid}

C13CPDp1.PU CDCl3 /opt/topspin3.0 cschuste 50

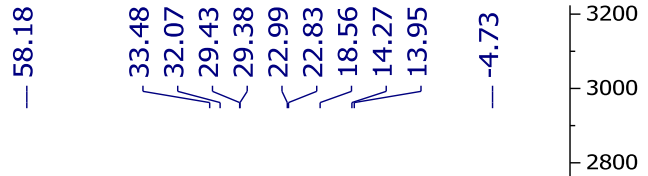

$-2800$

$-2600$

2400

$\overbrace{\mathrm{Si}(\mathrm{OEt})_{2} \mathrm{Me}}$

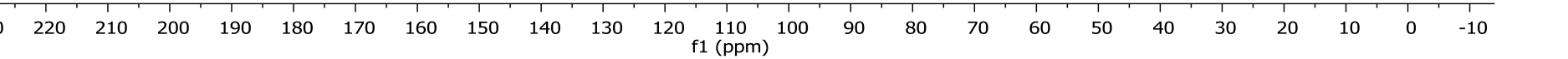




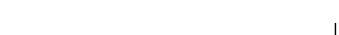

$\sim_{\mathrm{Si}(\mathrm{OE} t) \mathrm{Me}_{2}}$

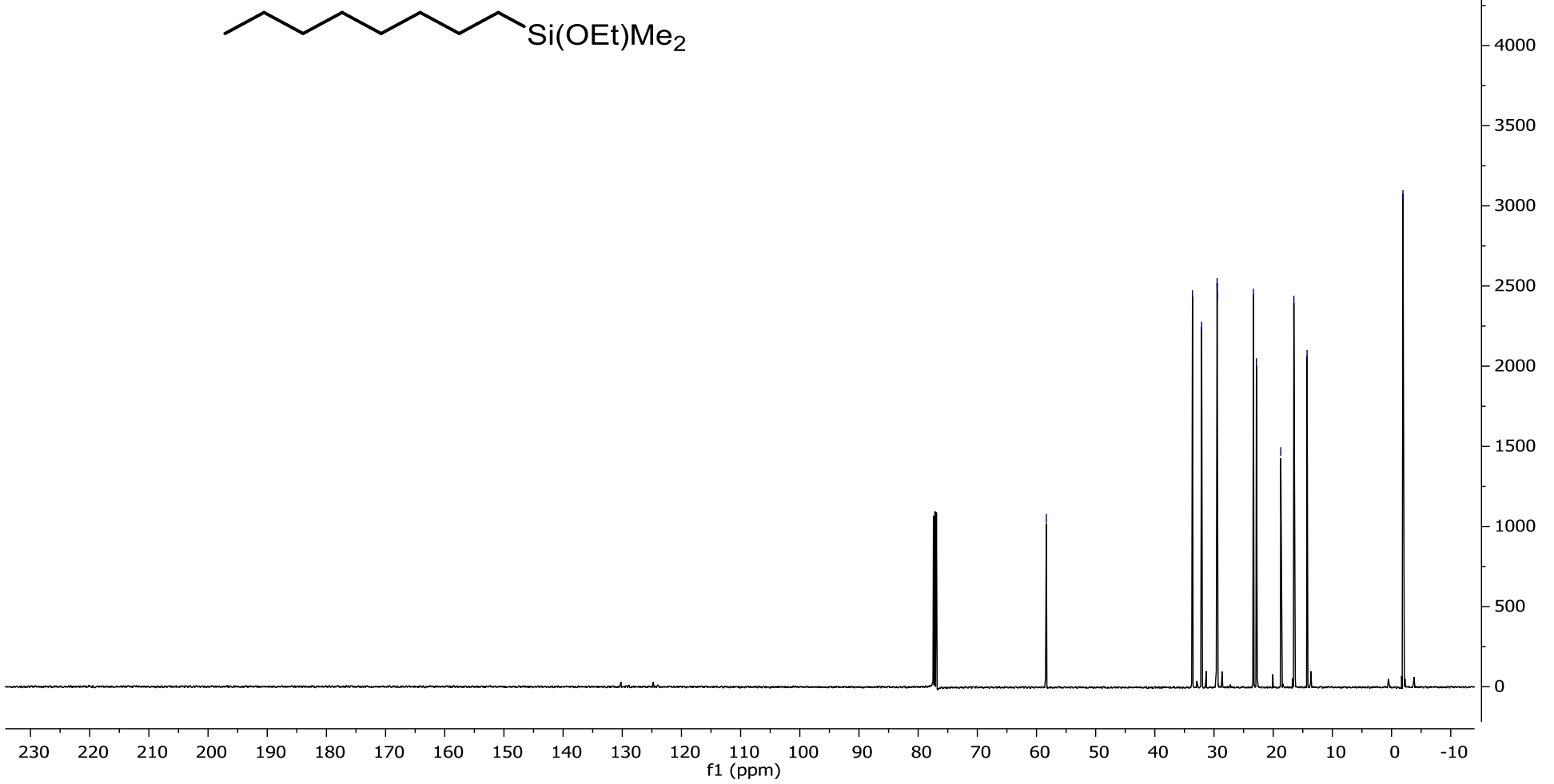



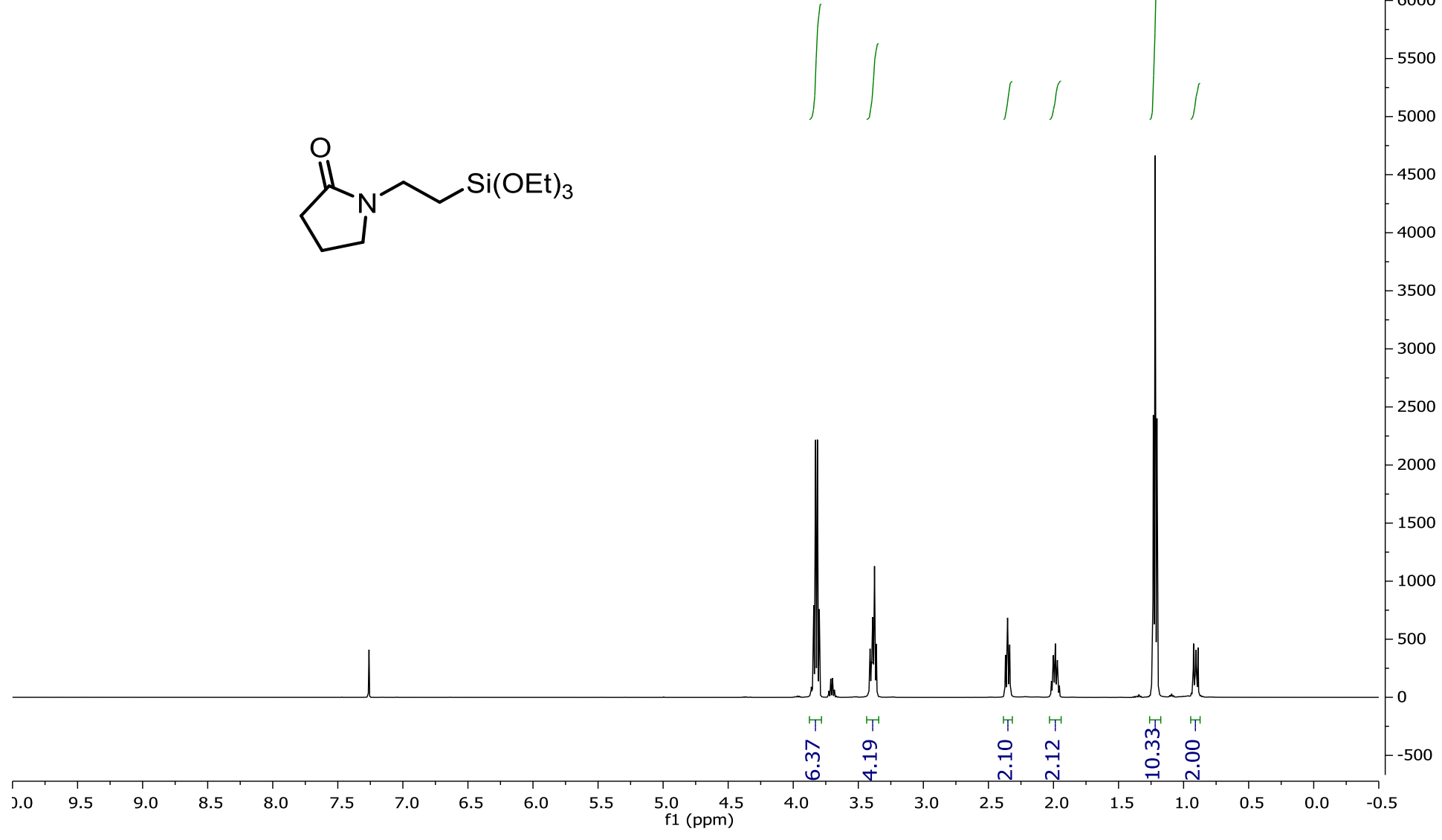

A2_46-CHS-3-176-13c.10.fid in C13CPDp1.PU CDCl3 /opt/topspin3.0 cschus

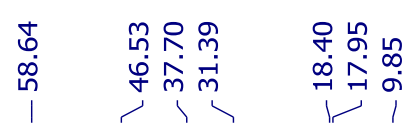

मे
$-3000$<smiles>O=C1CCCN1CC[GeH2]O</smiles>

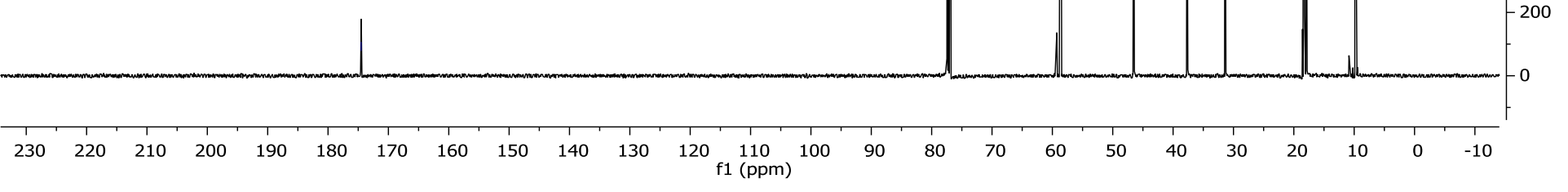



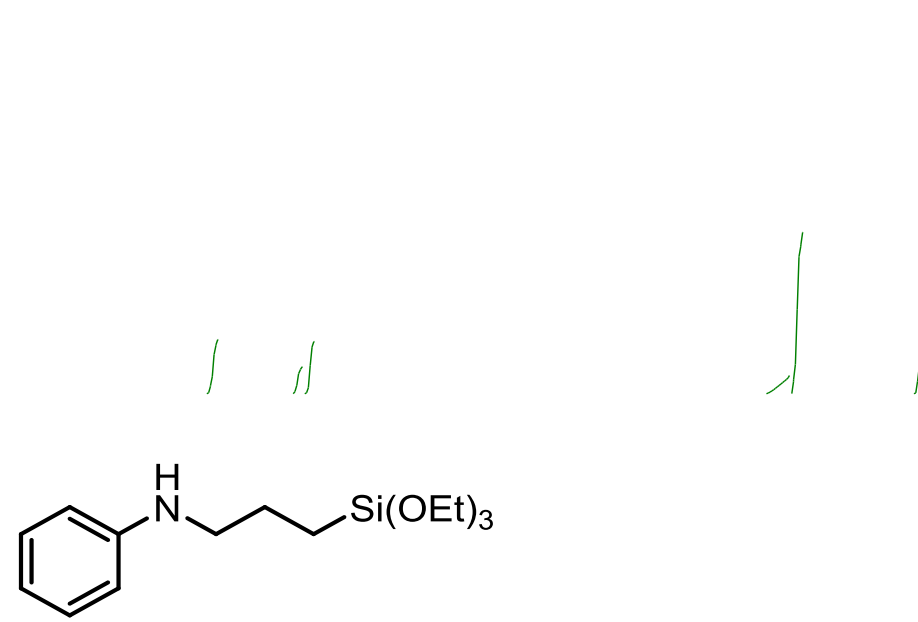

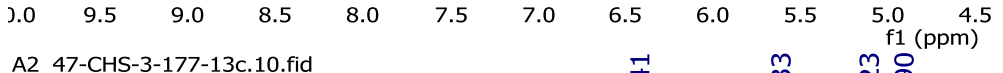

C13CPDp1.PU CDCl3 /opt/topspin3.0 cschuste 47

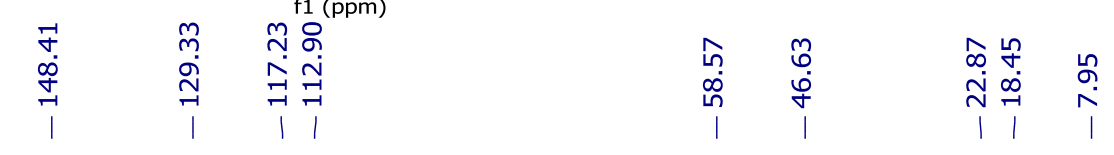

$\mathrm{N}^{\mathrm{N}} \mathrm{Si}^{\mathrm{O}(\mathrm{OEt})_{3}}$

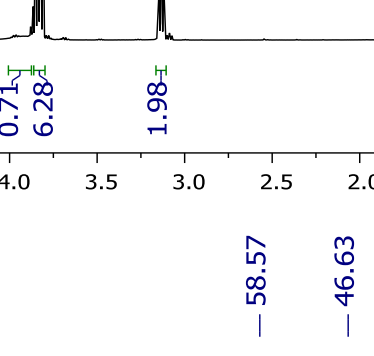

a.
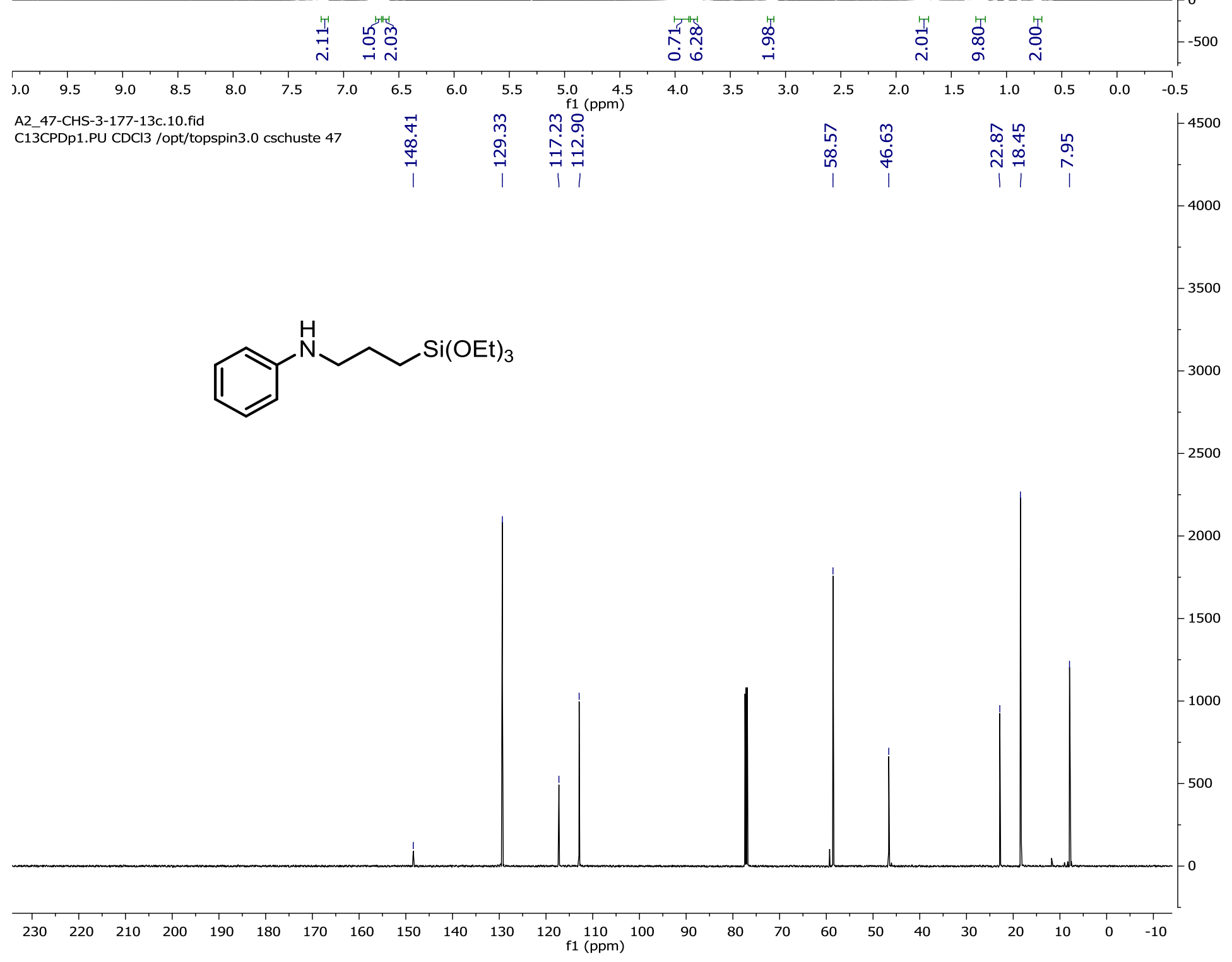
$\overbrace{\mathrm{O}}^{\mathrm{O}} \sim_{\mathrm{Si}(\mathrm{OEt})_{3}}$

\begin{tabular}{lllllllllll}
\hline 9.5 & 9.0 & 8.5 & 8.0 & 7.5 & 7.0 & 6.5 & 6.0 & 5.5 & $\begin{array}{c}5.0 \\
\mathrm{f} 1(\mathrm{ppm})\end{array}$
\end{tabular}

ơ

స్용 A2_57-CHS-3-204.11.fid
C13CPDp1.PU CDCl3 /opt/topspin3.0 cschusste 57

I-

监 $\sim^{\mathrm{Si}(\mathrm{OEt})_{3}}$

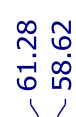

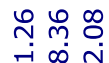

तi $\underset{\sim}{\infty} \stackrel{-1}{\sim}$

I 1

5500 $-5000$ 4500 $-4000$ $-3500$ $-3000$ 2500 2000

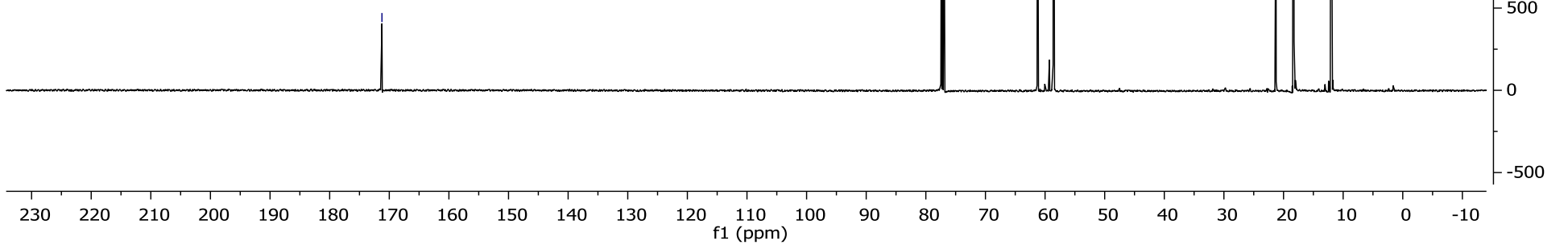



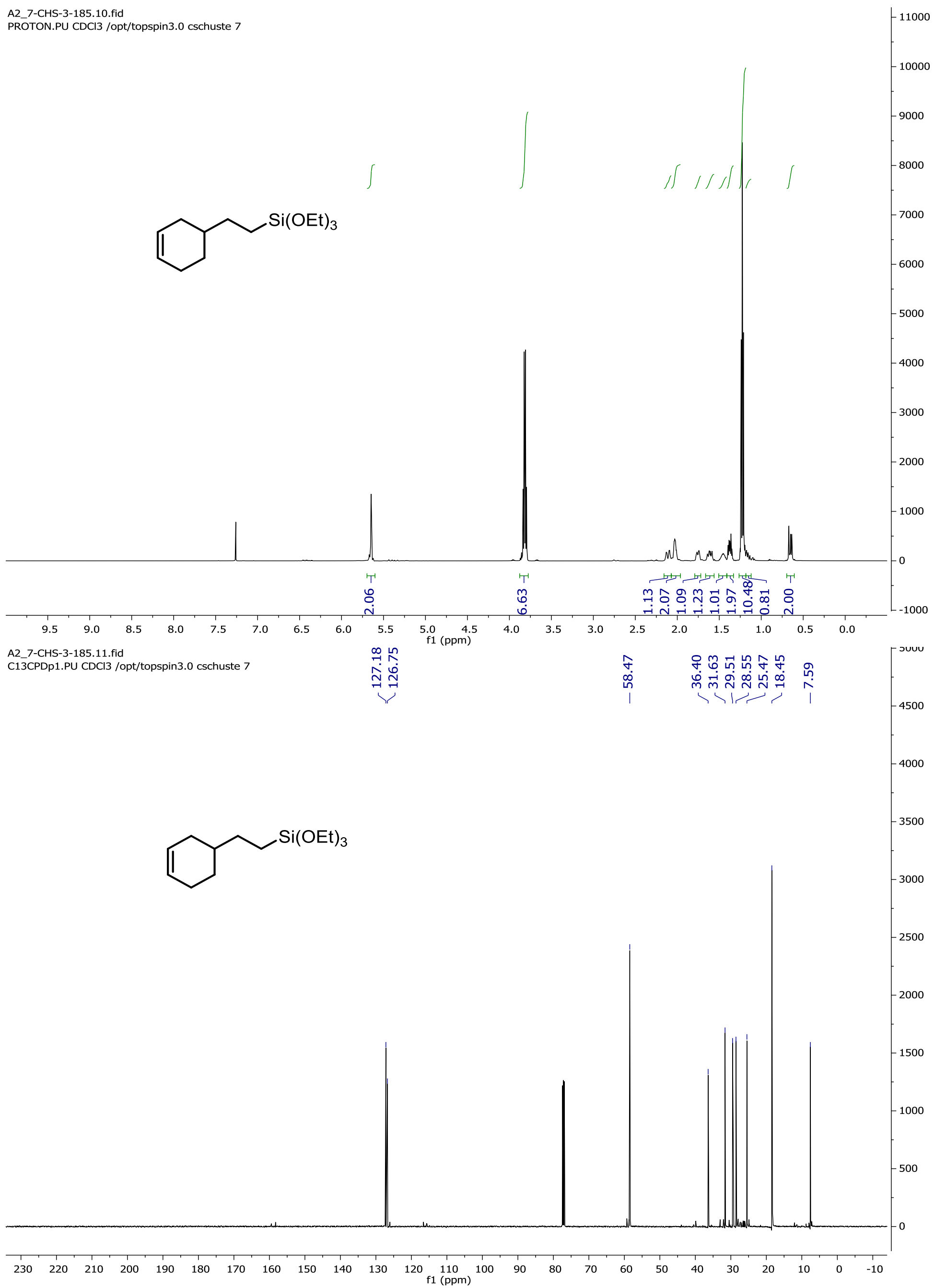

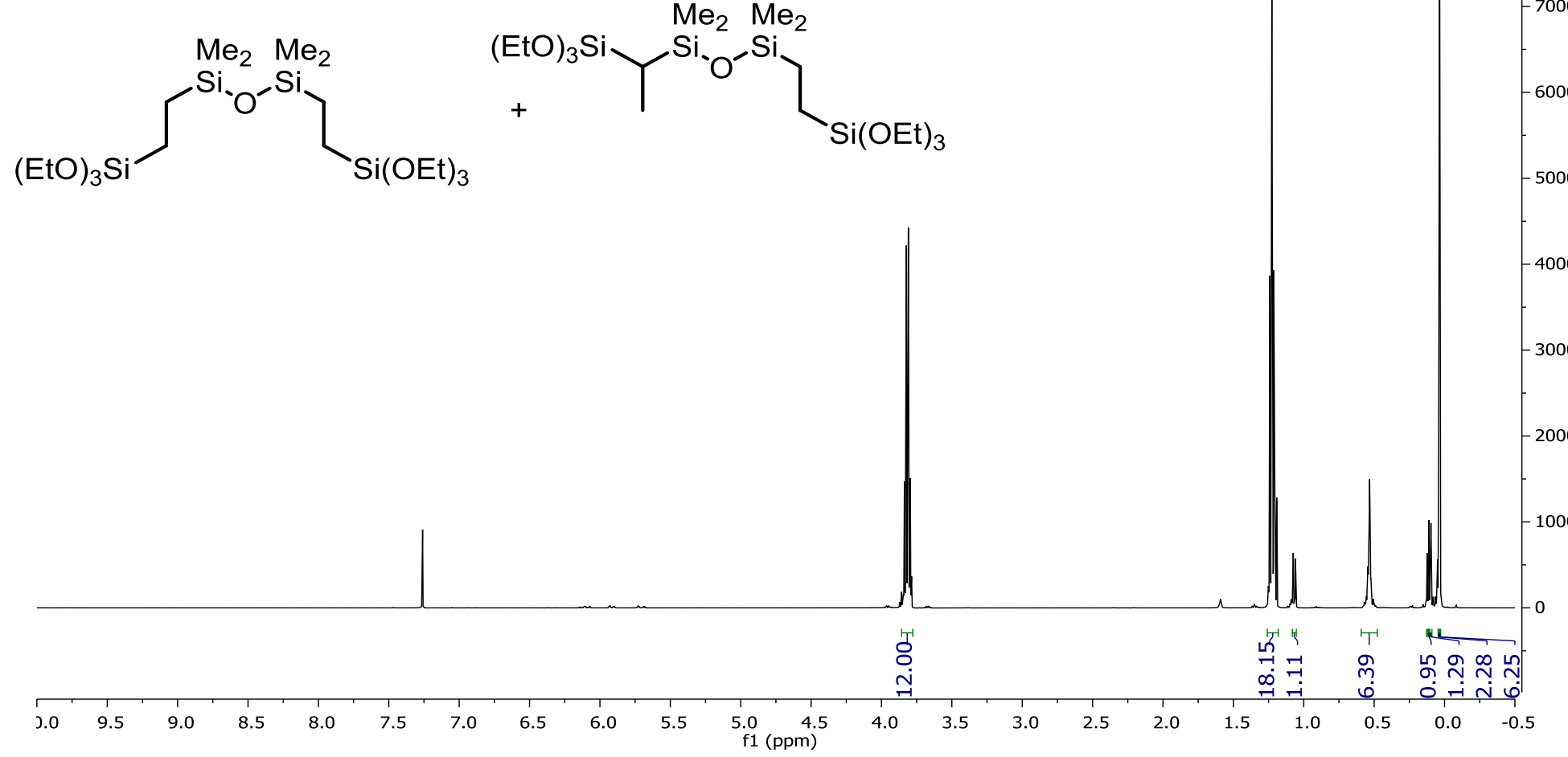

A2_8-CHS-3-186.11.fid

C13CPDp1.PU CDCI3 /opt/topspin 3.0 cschuste 8
ก้ ก

$\infty \infty^{\infty}$

ஸे

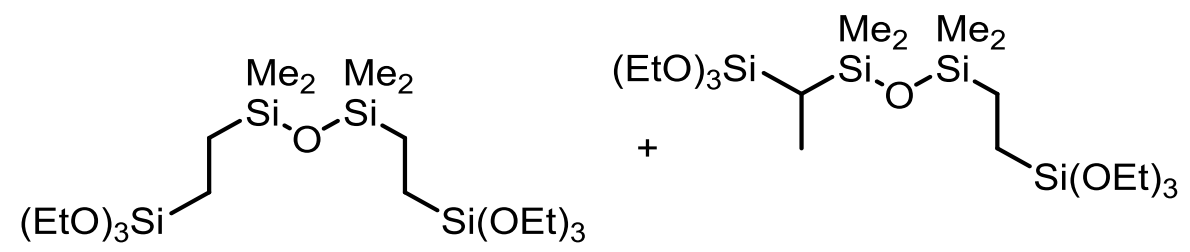

$\mathrm{Me}_{2} \quad \mathrm{Me}_{2}$

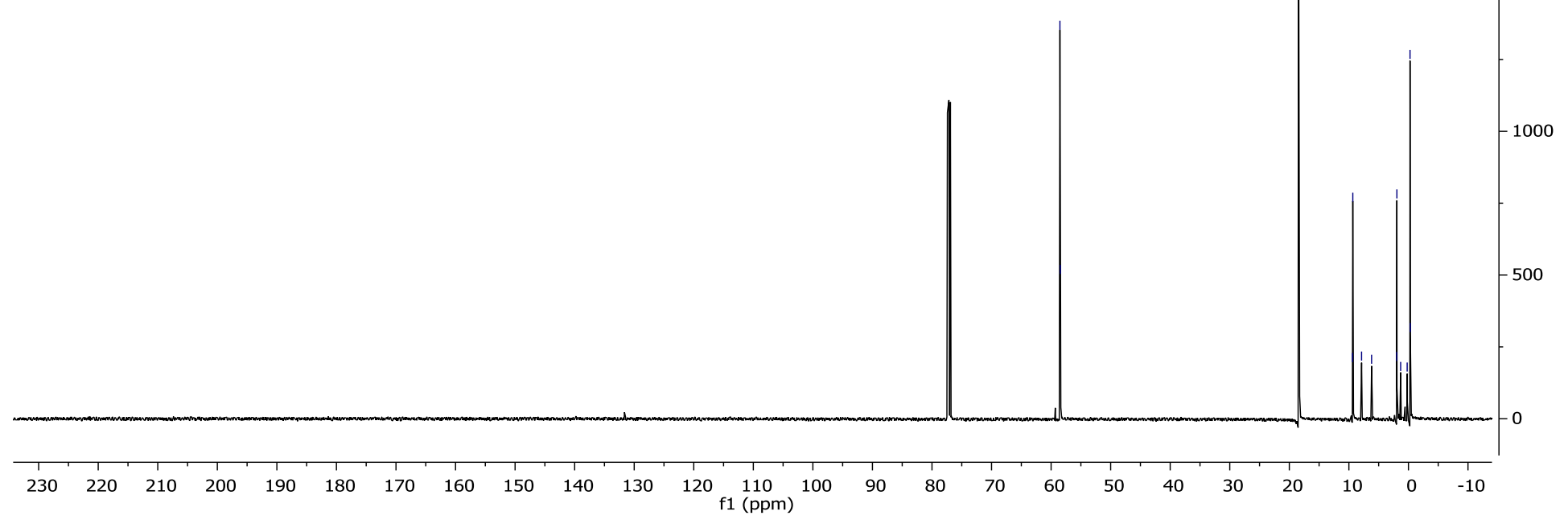




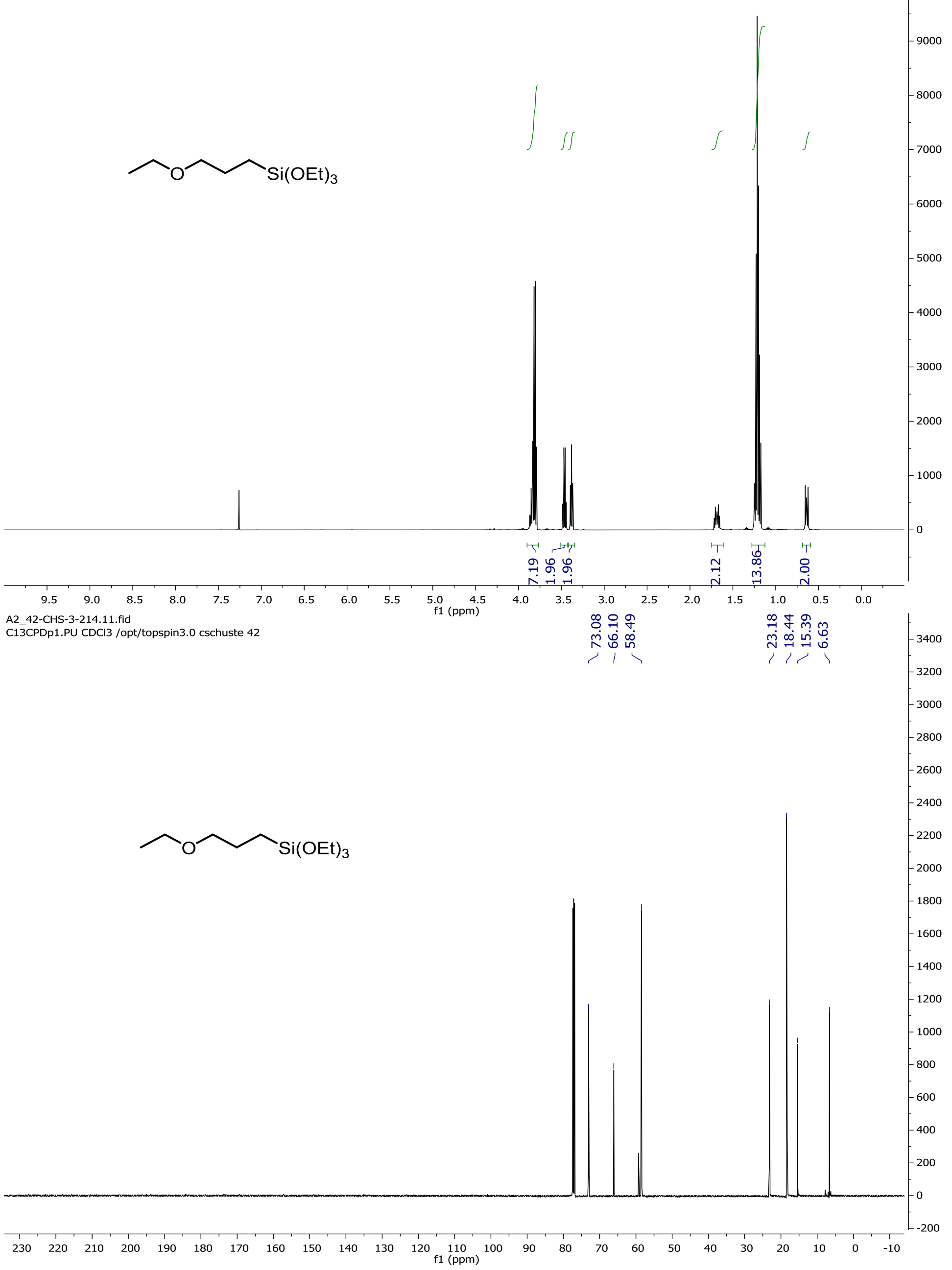




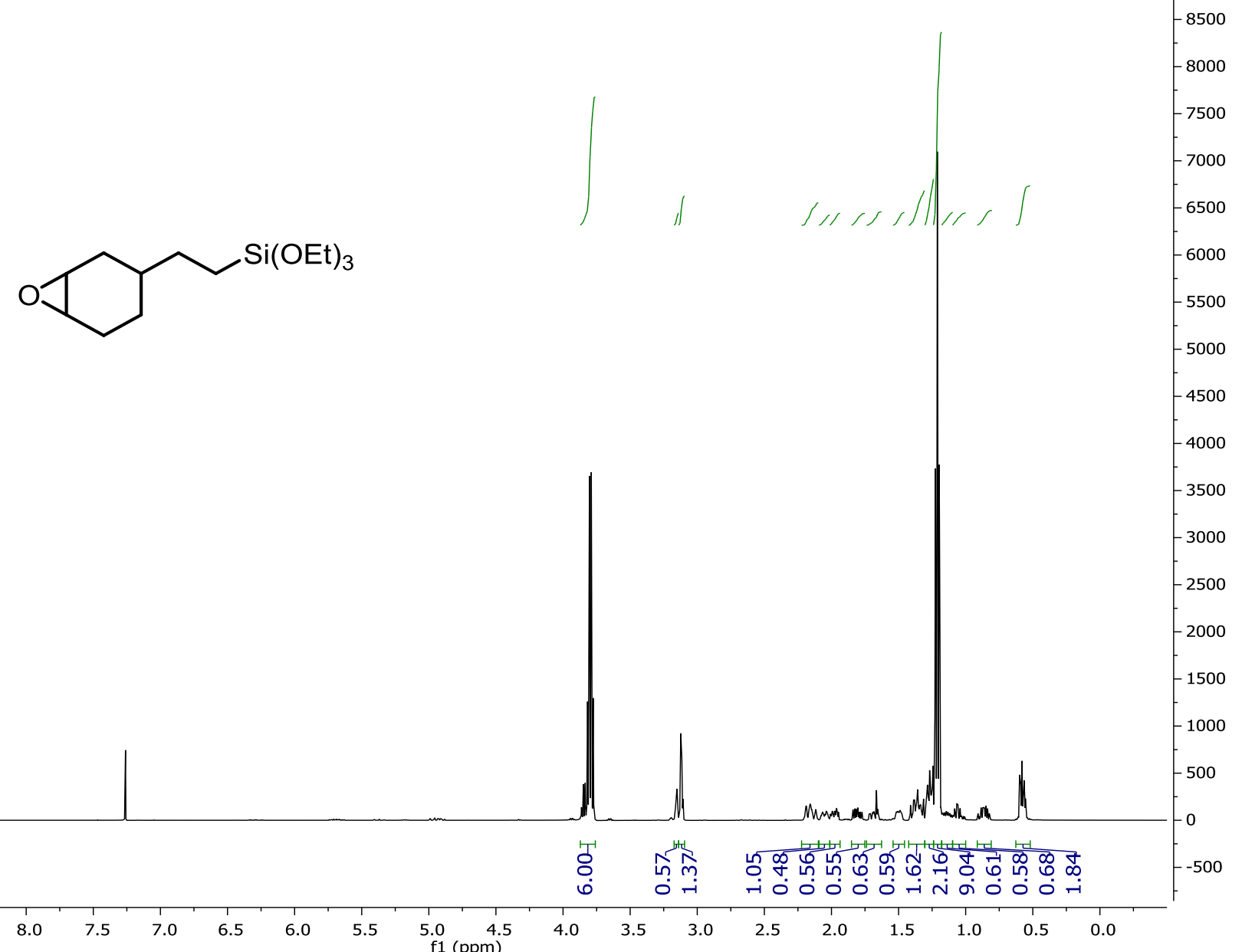




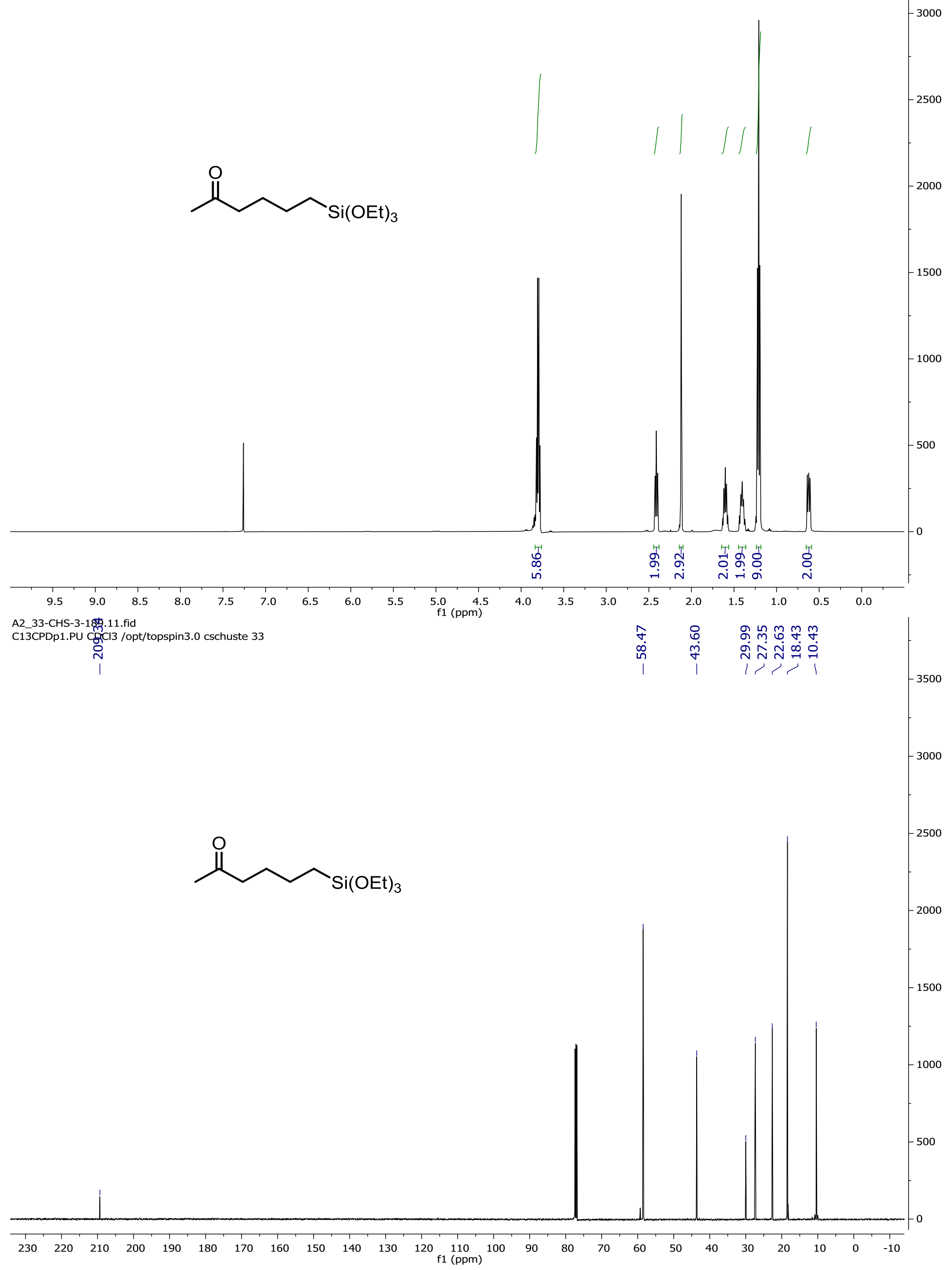




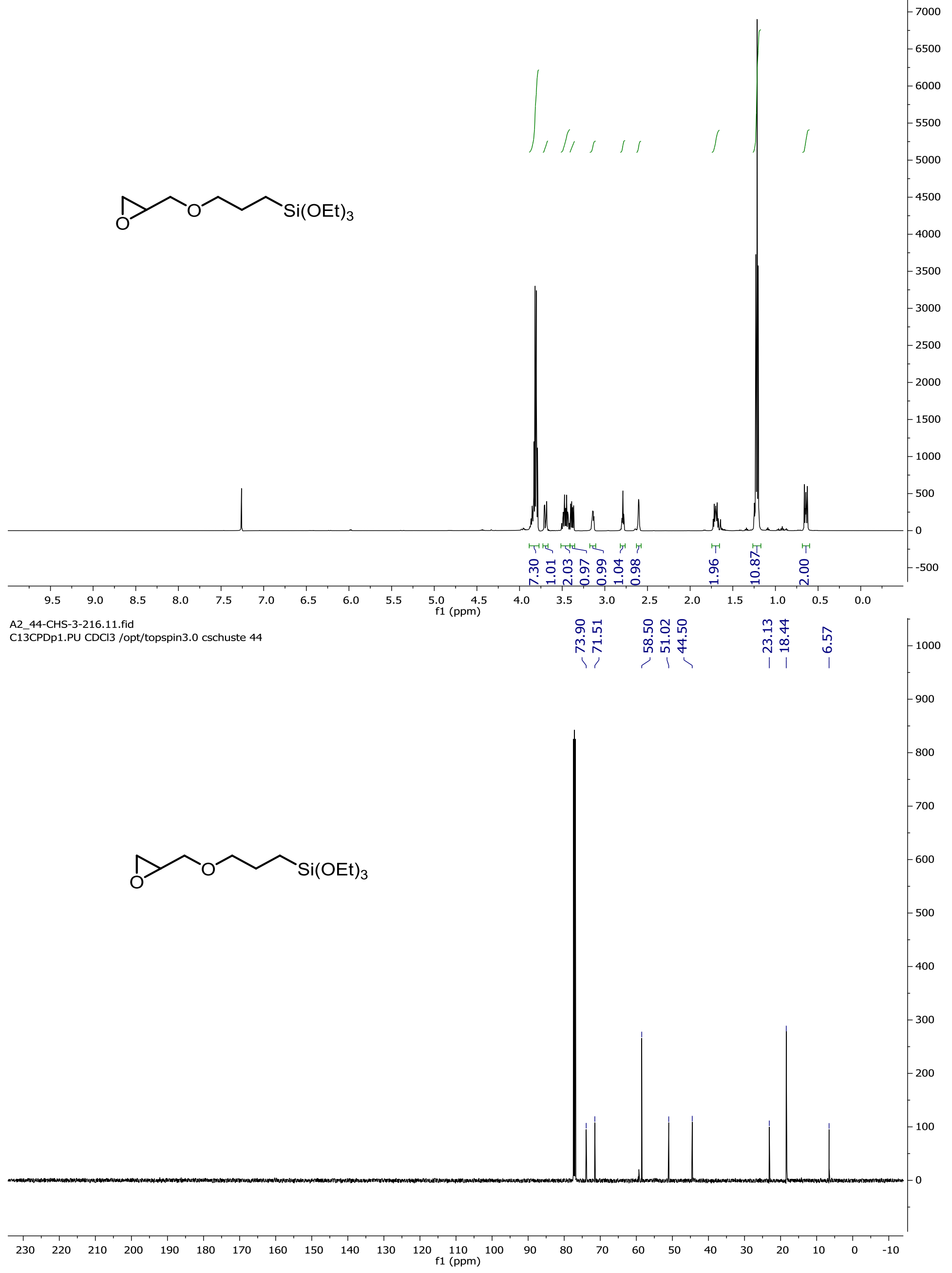


$\overbrace{D} \mathrm{Si}(\mathrm{OEt})_{3}$
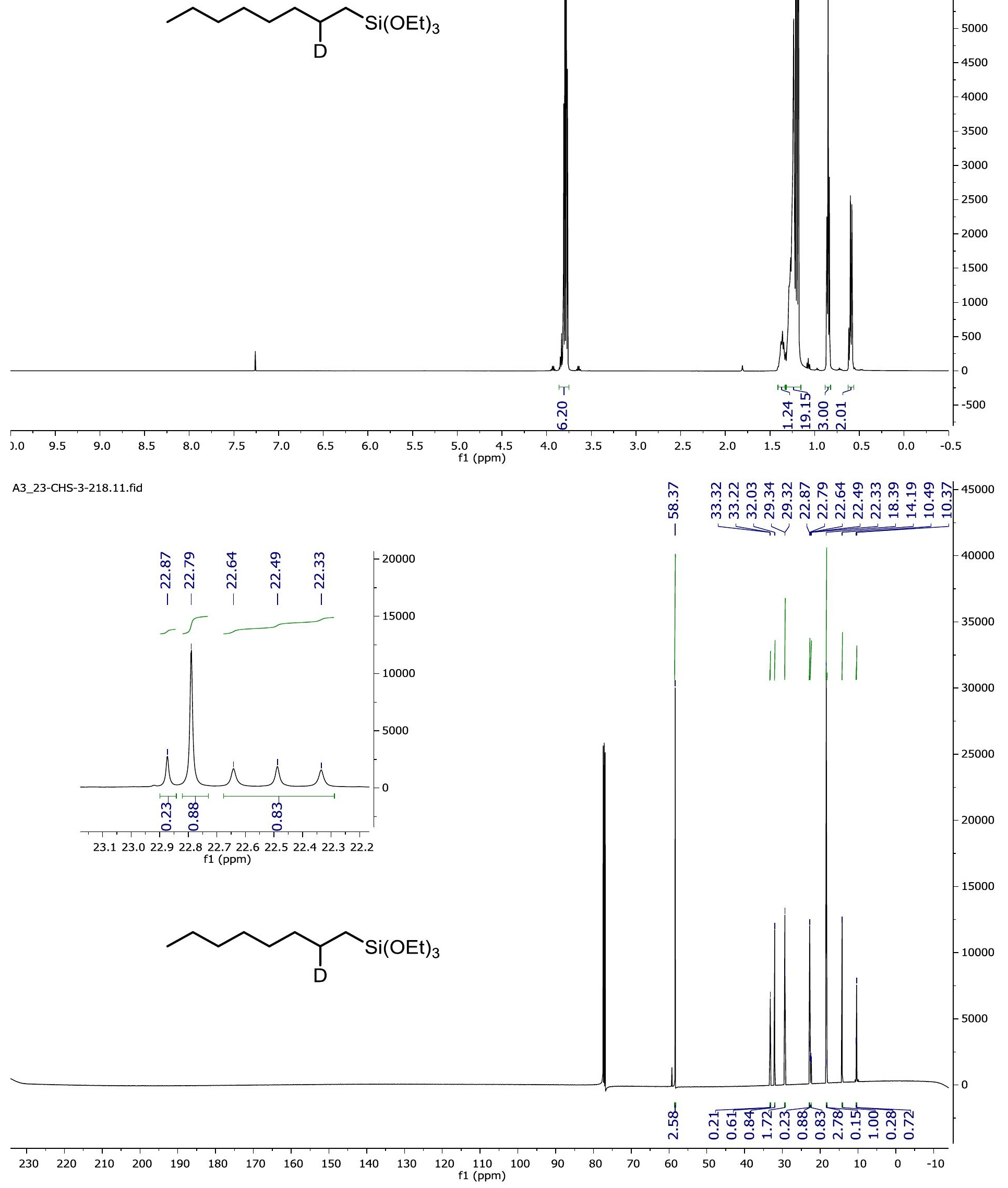


\section{${ }^{2} \mathrm{H}$ NMR Spectrum}

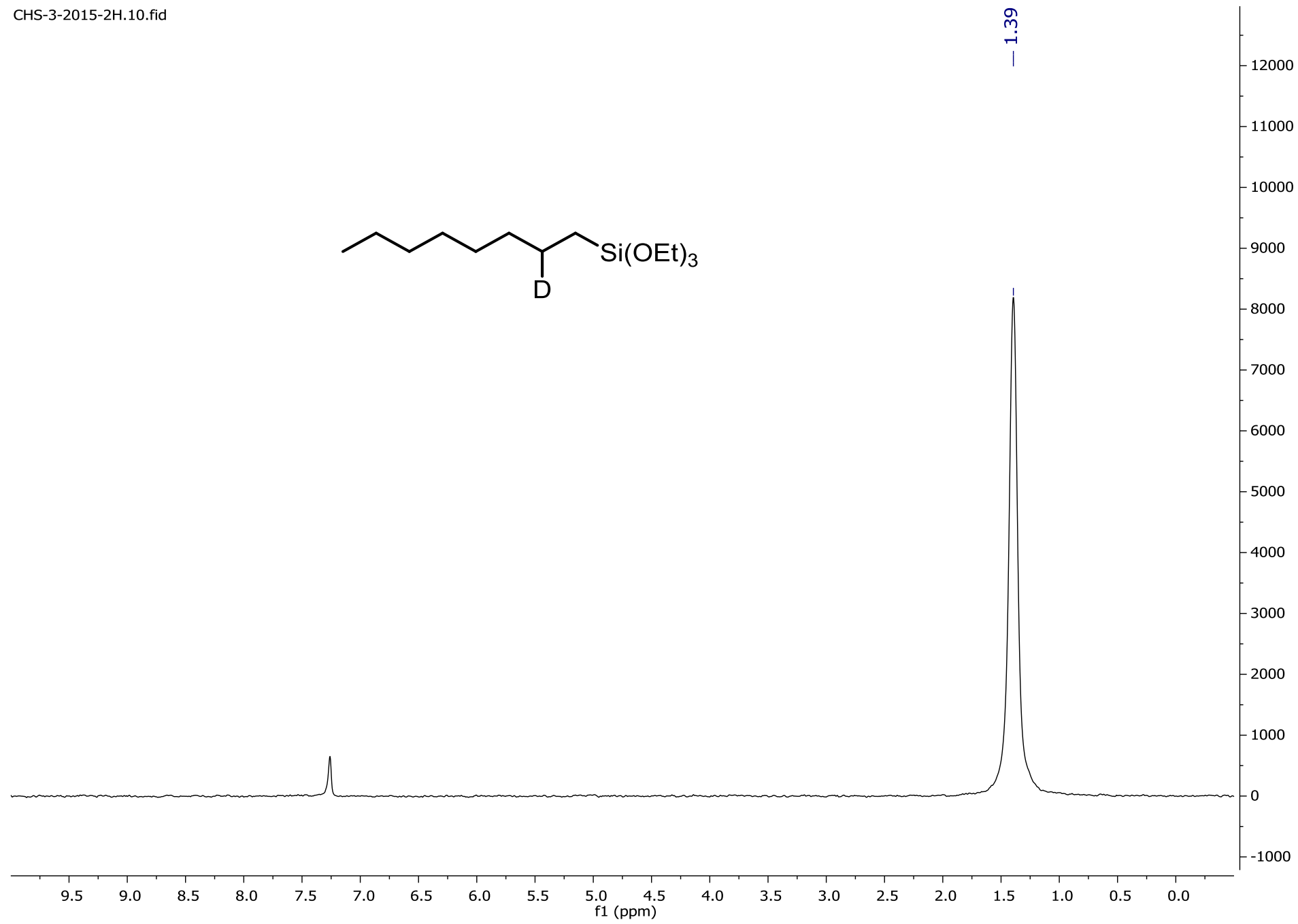



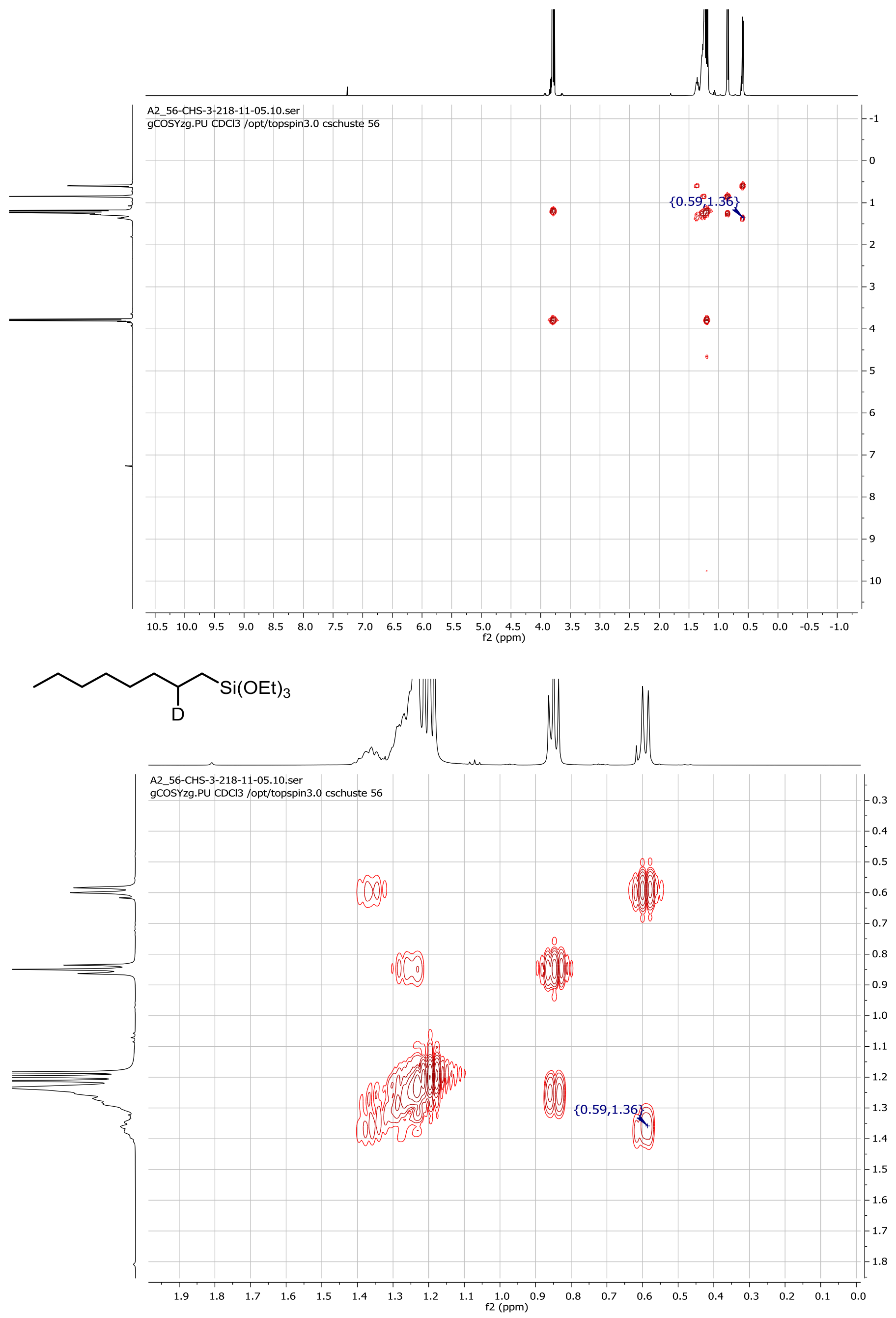


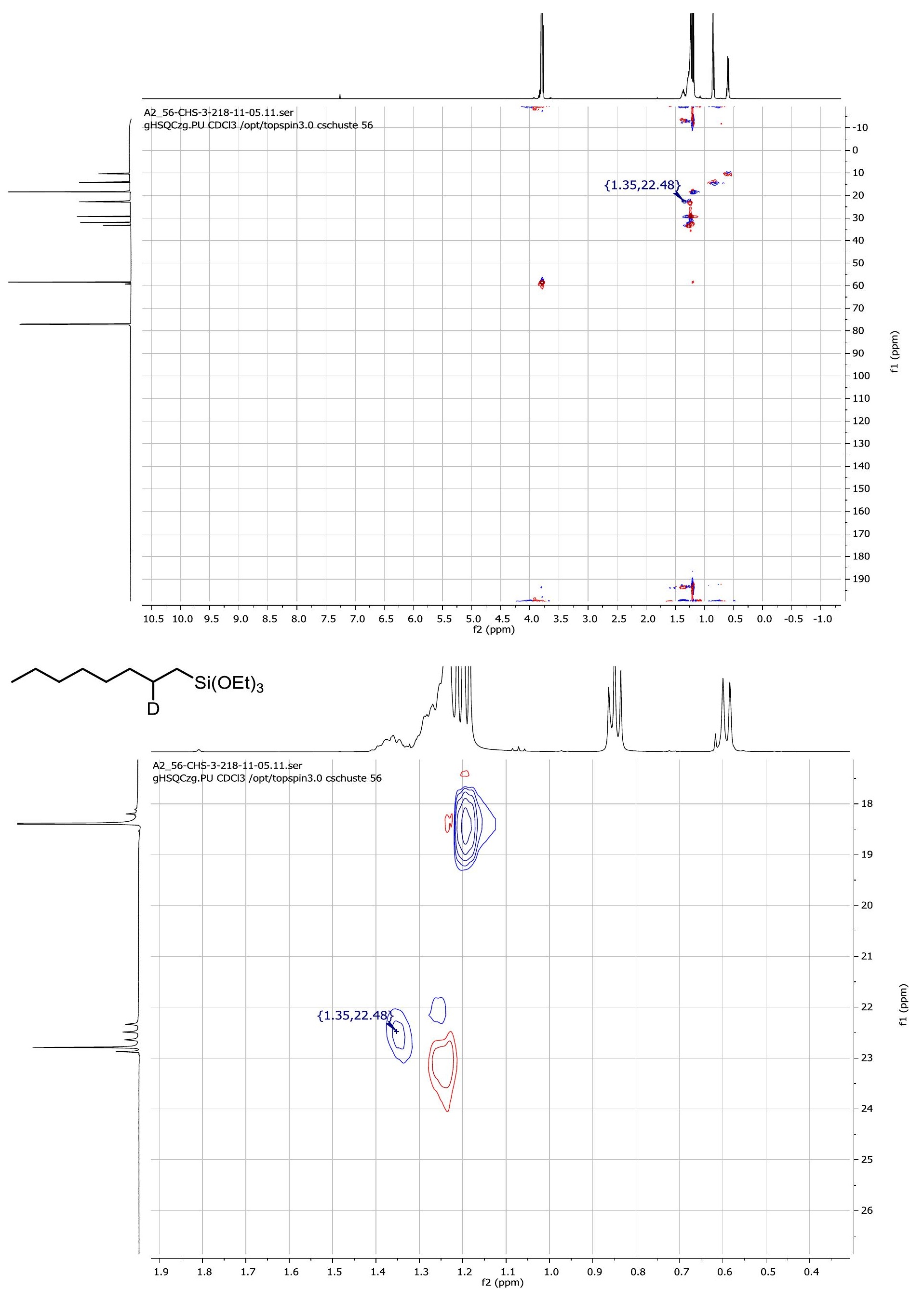




\section{References}

(1) Pangborn, A. B.; Giardello, M. A.; Grubbs, R. H.; Rosen, R. K.; Timmers, F. J. Organometallics 1996, 15, 1518.

(2) Zhu, Y-Y.; Cui, C.; Li, N.; Wang, B-W.; Wang, Z-M.; Gao, S. Eur. J. Inorg. Chem. 2013, 3101.

(3) Bernauer, K.; Gretillat, F. Helv. Chim. Acta 1989, 72, 477.

(4) Tondreau, A. M.; Atienza, C. C. H.; Weller, K. J.; Nye, S. A.; Lewis, K. M.; Delis, J. G. P.; Chirik, P. J. Science 2012, 335, 567.

(5) Sunada, Y.; Noda, D.; Soejima, H.; Tsutsumi, H.; Nagashima, H. Organometallics 2015, 34, 2896.

(6) Atienza, C. C. H.; Diao, T.; Weller, K. J.; Nye, S. A.; Lewis, K. M.; Delis, J. G. P.; Boyer, J. L.; Roy, A. K.; Chirik, P. J. J. Am. Chem. Soc. 2014, 136, 12108.

(7) Pichon, B. P.; Man.; M. W. C.; Bied, C.; Moreau, J. J. E. J. Organomet. Chem. 2006, $691,1126$.

(8) Bai, Y.; Peng, J.; Li, J.; Lai, G. Appl. Organomet. Chem. 2011, 25, 400.

(9) Aromi, G.; Batsanov, A. S.; Christian, P.; Helliwell, M.; Parkin, A.; Parsons, S.; Smith, A. A.; Timco, G. A.; Winpenny, R. E. P. Chem. Eur. J. 2003, 9, 5142. 